\title{
The Good, the Bad, and the Ugly of Online Reviews: The Trouble with Trolls and a Role for Contract Law after the Consumer Review Fairness Act
}

Wayne Barnes

Texas A\&M University School of Law, wbarnes@law.tamu.edu

Follow this and additional works at: https://scholarship.law.tamu.edu/facscholar

Part of the Consumer Protection Law Commons, Contracts Commons, and the Internet Law Commons

\section{Recommended Citation}

Wayne Barnes, The Good, the Bad, and the Ugly of Online Reviews: The Trouble with Trolls and a Role for Contract Law after the Consumer Review Fairness Act, 53 Ga. L. Rev. 549 (2019).

Available at: https://scholarship.law.tamu.edu/facscholar/1305

This Article is brought to you for free and open access by Texas A\&M Law Scholarship. It has been accepted for inclusion in Faculty Scholarship by an authorized administrator of Texas A\&M Law Scholarship. For more information, please contact aretteen@law.tamu.edu. 


\section{THE GOOD, THE BAD, AND THE UGLY OF ONLINE REVIEWS: THE TROUBLE WITH TROLLS AND A ROLE FOR CONTRACT LAW AFTER THE CONSUMER REVIEW FAIRNESS ACT}

Wayne R. Barnes*

The advent of the internet has brought innumerable innovations to our lives. Among the innovations is the meteoric rise in the volume of e-commerce conducted on the internet. Correspondingly, consumer-posted information about merchants, goods, and services has also become a rich source of information for consumers researching a purchase online. This information takes many forms, but a major category is the narrative review describing the purchase and experience. Such reviews are posted on websites such as Yelp, Amazon, and TripAdvisor, on apps, and on social media such as Facebook and Twitter. The amount and volume of reviews has exploded in recent years, and these reviews have taken on great significance in the shopping experiences of millions of consumers. Indeed, positive reviews can greatly enhance a company's profitability, while a negative review can have devastating effects. Some negative reviews are simply defamatory; some, while couched in opinion form, are extraordinarily and virulently negative. Such reviews are part of a larger online phenomenon known as the "online disinhibition effect," or, more simply - internet trolls. Some companies had begun using non-disparagement clauses to contractually prohibit negative reviews. But the public reacted negatively to the attempt to completely ban

\footnotetext{
* Professor, Texas A\&M University School of Law. I would like to thank Texas A\&M University School of Law for its generous research assistance provided for this article. Thanks also to my colleagues Bill Henning and Frank Snyder for their helpful comments while formulating the theses of this Article.
} 
reviews from being posted online, and in 2016 Congress enacted the Consumer Review Fairness Act which was intended to largely prohibit the use of clauses preventing such reviews. However, the concern of companies regarding the "troll-like" virulent reviews, often posted solely for vengeance purposes, remains valid. This Article posits that the Consumer Review Fairness Act still allows contract clauses which prohibit reviews that are defamatory, and also reviews that are "abusive." Abusive reviews which should still be contractually prohibitable include the virulent, excessively negative "troll-like" reviews. (One important caveat-to date, California, Maryland, and Illinois have enacted their own state laws banning non-disparagement clauses, which do not presently contain the "abusive" exception as does the CRFA, and thus merchants subject to these laws cannot ban any consumer reviews of any type-troll or otherwise). Moreover, this Article further argues that the implied duty of good faith and fair dealing can be argued to prohibit such abusive reviews, regardless of the presence of an express clause banning reviews. 


\section{TABLE OF CONTENTS}

I. INTRODUCTION.

II. E-COMMERCE, ONLINE REVIEWS, AND THE ADVENT OF NON-

DisPaRAGEMENT ClaUses IN THE CONSUMER CONTEXT .. 556

A. THE GROWTH OF CONSUMER E-COMMERCE ................. 556

B. THE RISE OF ONLINE REVIEWS AND THEIR INFLUENCE ... 558

C. TYPES OF REVIEWERS AND REVIEWS: THE GOOD, THE BAD,

AND THE UGLY .................................................. 562

1. Positive Reviews..................................................... 564

2. Negative (but Factual) Reviews............................ 565

3. Extremely Negative Reviews (Troll Alert!) .............. 567

D. MERCHANTS STRIKE BACK: THE RISE OF THE NON-

DISPARAGEMENT CLAUSE .................................... 576

III. The CONSUmER REVIEW FAIRnESs ACT........................... 582

A. THE TEXT OF THE ACT ............................................ 583

B. THE EFFECT OF THE CRFA ON CURRENT PRACTICE ........ 586

C. ADDRESSING OBJECTIONS TO THIS ARTICLE'S STATUTORY

ANALYSIS OF CFRA ................................................. 590

1. Statutory Provisions at Issue................................ 591

2. Goldman's Arguments .......................................... 593

a. "Submission" only applies to consumer review services ........................................................... 595

b. A consumer review is not a "disclosure"........... 595

c. The word "abusive" is constrained by the introductory language in the Paragraph (2)(C) exclusion........................................................... 596

d. Paragraph (2)(C)'s limitation to consumer review services means that Paragraph (3)(D) is so limited ................................................... 596

e. Is "abusive content" grammatically incorrect?... 597

3. Goldman's arguments Run Afoul of the Federal

Trade Commission Guidance and Other

Interpretations of CRFA .................................... 597

D. ONE CAUTION—DIVERGENT STATE LAWS .................... 599 
IV. Consumer Reviews, Trolls, AND THE DUTY OF GoOD

FAITH AND FAIR DEALING............................................... 601

A. THE DUTY OF GOOD FAITH AND FAIR DEALING ................ 601

B. APPLICATION OF THE DUTY OF GOOD FAITH AND FAIR DEALING TO ABUSIVE CONSUMER REVIEWS ................. 603

C. ADDRESSING POTENTIAL CONSTITUTIONAL CONCERNS .. 605

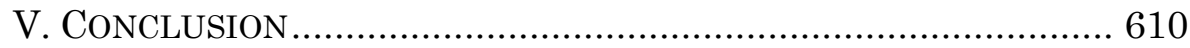




\section{INTRODUCTION}

The internet is increasingly a dominant forum for researching and purchasing goods and services. ${ }^{1}$ The amount of information about companies, providers, goods and services has seemingly never been more vast. That information includes the explosion of online reviews, which have become a significant part of the e-shopping experience for millions of consumers. Consumers describe their experiences on various review-specific sites such as Yelp, Amazon, Angie's List, and Epinions, and also on social media platforms such as Twitter and Facebook. ${ }^{2}$ These sites and platforms have created an apparent benefit for consumers insofar as they are able to gather published information about goods or services and the merchants who sell them. ${ }^{3}$

However, merchants' perspective on such online reviews is different. Merchants value their brand and their reputations. ${ }^{4}$ Online reviews have the ability to make or break businesses. ${ }^{5}$ Sometimes the reviews are very favorable (e.g., "this product

1 See Tanya M. Marcum \& Sandra J. Perry, Boiling Mad Consumers Over Boilerplate Language: Non-Disparagement Clauses in Online Sales Contracts, 68 LAB. L.J. 982501 (2017) ("Customers are increasingly using the internet to research and purchase items.").

2 See, e.g., Chris Zook, 20 Business Review Sites to Help Your Small Business, FX BLOG, https://www.webpagefx.com/blog/internet/20-business-review-sites-help-small-business/ (last visited Dec. 12, 2017) (providing a list of twenty sites to use for online reviews).

3 The benefit to consumers depends, of course, on the genuineness and accuracy of the reviews. "Fake reviews"- both good ones created by the merchant and bad ones created by competitors-are a serious problem in the online review world. See, e.g., Emma Woollacott, Amazon's Fake Review Problem Is Now Worse Than Ever, Study Suggests, ForBes (Sept. 9, 2017, 12:13 PM), https://www.forbes.com/sites/emmawoollacott/2017/09/09/exclusiveamazons-fake-review-problem-is-now-worse-than-ever/\#4663e4517c0f (describing how fake reviews on Amazon can push some products ahead of others to the detriment of the customer and vendor).

4 See Lucille M. Ponte, Protecting Brand Image or Gaming the System? Consumer "Gag" Contracts in an Age of Crowdsourced Ratings and Reviews, 7 WM \& MARY BUs. L. REV. 59, 62 (2016) ("Businesses invest a great deal of time, effort, and expense into developing their brand and building customer relationships.").

5 See id. at 92 ("A 2011 Harvard Business School study found that independent restaurants reaped a 5 to 9 percent increase in their revenues when their Yelp ratings rose about one star higher. Conversely, the posting of a single negative review online could cause business revenues to plummet about 25 percent or more.”); L. David Russell, Christopher C. Chiou \& Zain A. Shirazi, Fake It Until You Make It? Battling Fake Online Reviews, Law360 (June 9, 2014, 12:17 PM), https://www.law360.com/articles/545366/fake-it-until-you-make-itbattling-fake-online-reviews ("San Francisco restaurants, for example, are almost 50 percent more likely to sell out their evening reservations with just a half-star upgrade to their Yelp rating.”). 
performs wonderfully, and I would recommend it to anyone"). Sometimes they are negative but factually-based (e.g., "the hotel room was not clean; there were wet towels in the bathroom when we checked in, and it was apparent that the bed sheets had not been changed since the last guest checked out."). Other times they are outright false or defamatory (e.g., "the steak was raw to the point of being unhealthy" - when, in fact, the consumer had not dined at the restaurant and was simply trying to use the review to sabotage the restaurant's business). And sometimes the reviews are uninhibited, over-the-top hyperbole (e.g., "this company is the WORST EVER; I wouldn't wish them on my WORST ENEMY!!! This business is where hope and optimism go to DIE!!!!”). Due to this wide range of online reviews, some merchants have understandably sought to manage the risks associated with negative online reviews.

One tactic used by some merchants is to include a nondisparagement clause in the contract. ${ }^{6}$ Such clauses typically prohibit only negative reviews or critiques about the merchant or the goods or services it provides. ${ }^{7}$ However, in a handful of highprofile and widely-reported instances, use and enforcement of such clauses resulted in significant public opposition and criticism. ${ }^{8}$ As a result, California passed a law in 2014 banning such clauses, ${ }^{9}$ and Maryland passed a similar law in 2016. ${ }^{10}$ Shortly thereafter, Congress passed the Consumer Review Fairness Act, ${ }^{11}$ which essentially prohibits non-disparagement clauses in consumer

6 Ponte, supra note 4 , at 67.

7 Id.

8 See Tim Cushing, Law Passed to Protect Customers from Non-Disparagement Clauses and Other Ridiculous Restrictions, TECHDIRT (Dec. 7, 2016, 1:03 PM), https://www.techdirt.com/articles/20161206/07004036204/law-passed-to-protect-customersnon-disparagement-clauses-other-ridiculous-restrictions.shtml ("Companies are still including non-disparagement clauses in contracts, despite there being ample evidence all it really does is generate massive amounts of disparagement from parties not bound by the contractual language.”).

9 See Doug Gross, Yelp without fear, says new California law, CNN.Com (Sept. 12, 2014, 2:43 PM), http://www.cnn.com/2014/09/12/tech/web/california-law-yelp/index.html (describing the new law and its effects).; CAL. CIV. CODE $§ 1670.8$ (West 2015).

10 See The 'Right to Yelp' Is Now Maryland Law, NFIB (July 19, 2016), https://www.nfib.com/content/news/legal/the-right-to-yelp-is-now-maryland-law-74679/ (describing the Maryland law and its impact on non-disparagement clauses).

11 Elliot Harmon, President Signs Law Protecting Your Right to Review, ElECTRONIC FRONTIER Foundation (Dec. 21, 2016), https://www.eff.org/deeplinks/2016/12/presidentsigns-law-protecting-right-review; 15 U.S.C. $§ 45 b$ (2016). 
contracts nationwide, except for certain contexts (e.g., trade secrets, certain medical files, information collected for law enforcement purposes, and defamatory statements). Notably, the Act also purports not to be applicable to efforts to prohibit online reviews that are "abusive," although the Act does not define "abusive." Since the enactment of the Consumer Review Fairness Act, Illinois has become the third state to enact its own state law banning such nondisparagement clauses. ${ }^{12}$

In the aftermath of the federal Consumer Review Fairness Act, the issue of whether non-disparagement clauses could be used in the typical consumer context seems largely settled-they cannot. However, some questions remain. What is meant by the "abusive" exception of the Act? Are there still online reviews that can be prohibited as "abusive" even if they fall short of constituting defamation or otherwise presently actionable conduct? What kind of reviews? And, since the Act could be amended or repealed in the future, does independent contract law generally, and the duty of good faith and fair dealing specifically, have any bearing on the "wild west" of the world of online reviews posted by disgruntled consumers? This Article addresses these questions. Part II will discuss the rise of internet commerce and online reviews. It will also address the effects of such reviews on businesses and the rise of nondisparagement clauses, attempts at enforcing such clauses, and the public reaction. Part III will discuss the Consumer Review Fairness Act, and the limitations it places on the use of non-disparagement clauses. Part IV will discuss the contractual duty of good faith and fair dealing and explore its potential application to a certain category of online reviews which, arguably, should still be subject to prohibition by merchants seeking to protect their business and brand. Finally, Part V will present a conclusion.

12 See Alexia Elejalde-Ruiz, New Illinois Law Protects Consumers Who Post Negative Reviews to Sites Like Yelp, Chicago Tribune (Aug. 24, 2017, 6:10 AM), http://www.chicagotribune.com/business/ct-illinois-right-to-yelp-law-0824-biz-20170823story.html (describing the new Illinois law and its protections). 


\section{E-COMMERCE, ONLINE REVIEWS, AND THE ADVENT OF NON- DISPARAGEMENT CLAUSES IN THE CONSUMER CONTEXT}

Consumers are using the internet for commercial purposes more than ever before. ${ }^{13}$ Not only are they purchasing more goods and services online, they are also researching their purchases ahead of time. ${ }^{14}$ In many instances, other consumers have posted online reviews about prior experiences with the product, service, or selling merchant. Such online reviews have become a cornerstone of the consumer purchasing process. ${ }^{15}$ The reviews can be positive or negative, accurate or false, measured or hyperbolic. Therefore, business have attempted to manage the effects of online reviews on their reputations, including some who have begun including nondisparagement clauses in their contracts. ${ }^{16}$ The following section addresses the rise of e-commerce, the advent of online reviews and their characteristics, some merchants' use of non-disparagement clauses to prospectively prohibit negative online reviews, and the public reception of such use.

\section{A. THE GROWTH OF CONSUMER E-COMMERCE}

E-commerce is on an ever-increasing trajectory. Much has changed since the first online purchases in the early 1990 s. ${ }^{17}$ From that fairly modest beginning, Statista reports that as of 2016, 58.3\% of all internet users have purchased items online. ${ }^{18}$ Domestically, a recent study estimates that $96 \%$ of Americans purchase goods and

13 See Madeline Farber, Consumers Are Now Doing Most of Their Shopping Online, FoRTUNE (June 8, 2016), http://fortune.com/2016/06/08/online-shopping-increases (discussing a 2016 study that found consumers are now, for the first time, buying more goods online than in stores).

14 See Leanna Kelly, How Many People Shop Online?, CPCSTRATEGy BLOG (May 25, 2017), http://www.cpcstrategy.com/blog/2017/05/ecommerce-statistics-infographic/ (noting that 68\% of American consumers are influenced by online reviews when deciding to purchase online).

15 See 2017 STATE OF ONLINE REVIEWS, learn.podium.com/rs/841-BRM-380/images/ 2017-SOOR-Infographic.jpg (noting that $93 \%$ of consumers say online reviews have an impact on their purchase decisions).

16 See Ponte supra note 4, at 67 and accompanying text.

17 Two of the first e-commerce transactions were a Sting CD and a large Pizza Hut pizza in 1994. Tucker Shreiber, Proceed to Checkout: The Unexpected Story of How Ecommerce Started, SHOPIFY (Nov. 25, 2016), https://www.shopify.co.uk/blog/69521733-proceed-tocheckout-the-unexpected-story-of-how-ecommerce-started.

18 Digital Buyer Penetration Worldwide from 2016 to 2021, STATiSTA (last visited Nov. 7, 2018), https://www.statista.com/statistics/261676/digital-buyer-penetration-worldwide/. 
services online. ${ }^{19}$ According to the U.S. Census Bureau, total U.S. retail e-commerce sales were $\$ 115.3$ billion for the third quarter of 2017 (compared to $\$ 1.27$ trillion in overall retail sales). ${ }^{20}$ That represented a 3.6\% increase from the second quarter of $2017 .{ }^{21}$ More significantly, the 2017 third quarter figures represented a $15.5 \%$ increase compared to the retail e-commerce sales from the third quarter of 2016 (whereas overall retail sales increased 4.3\% compared to the previous year). ${ }^{22}$ Another marker of e-commerce's growing popularity is that Cyber Monday 2017 was the highest grossing online shopping day in American history with online sales totaling over $\$ 6.6$ billion. ${ }^{23}$ That day also constituted the first-ever $\$ 2$ billion mobile shopping day, comprising the amount of Cyber Monday sales made by smartphones or tablets. ${ }^{24}$ Suffice it to say, online shopping and e-commerce activity is taking place in greater volume than ever before. And the reasons are fairly well known. Online shopping offers many conveniences, such as being timeefficient, avoiding the logistics of crowded brick-and-mortar stores, and providing shoppers with a wider inventory than in physical stores. ${ }^{25}$ Beyond mere convenience, multiple factors influence shoppers to make their purchases online, including: price, available discounts, simplicity of web site design and navigation, brand reputation, and the availability of trustworthy reviews. ${ }^{26}$ As a result, the rise of e-commerce is unsurprising, and its presence is likely to grow in the future.

\footnotetext{
19 Kelly, supra note 14.

20 Quarterly Retail E-Commerce Sales: 3rd Quarter 2017, U.S. CENSUs BuREAU News (Nov. 17, 2017), https://www2.census.gov/retail/releases/historical/ecomm/17q3.pdf. All of the estimates cited herein were adjusted for seasonal variation, but not for price fluctuations. Id. $21 \quad I d$.

$22 \quad I d$.

23 Jason Del Rey, Cyber Monday was the First $\$ 2$ Billion Mobile Shopping Day in the U.S., RECODE (Nov. 28, 2017, 1:31 PM), https://www.recode.net/2017/11/28/16710490/cybermonday-2017-2-billion-mobile-online-shopping-record.

${ }_{24} I d$.

25 See Kelly, supra note 14 (listing a number of considerations that influence shoppers).

26 Id.
} 


\section{B. THE RISE OF ONLINE REVIEWS AND THEIR INFLUENCE}

Merchants care greatly about their brand, and they cultivate their reputation through advertising and marketing. ${ }^{27}$ Increased online sales are good for merchants, but the emergence of the internet and social media has also presented challenges. ${ }^{28}$ Many online venues and platforms have arisen, enabling consumers to leave comments and give reviews of products, services, and merchants. ${ }^{29}$ These venues are multiple and varied. Many sites, such as Amazon, have consumer reviews built directly into the ecommerce merchant website (or app) itself. ${ }^{30}$ In fact, Amazon's success can be at least partially attributed to the rich volume of online reviews posted by past purchasers and available to shoppers. ${ }^{31}$ However, Amazon is only one source. Some of the reviews and consumer interactions occur on social media sites like Facebook, Reddit, and Twitter. ${ }^{32}$ Other reviews are posted on

27 See Ponte, supra note 4, at 62 (citing Paul W. Garrity, Advertising Regulation in the Web 2.0 World, METRO. CoRP. COUNSEL (Nov. 2, 2010), http://www.metrocorpcounsel.com/ articles/13197/advertising-regulation-web-20-world [http://perma.cc/SF5Q-6QBH]; JONAH BERGER, CONTAGIOUs: WHY THINGS CATCH ON 64 (2013) (noting that merchants put a great deal of time and effort in building relationships with customers); Sonia K. Katyal, Stealth Marketing and Anti-Branding: The Love That Dare Not Speak Its Name, 58 BuFf. L. REv. 795, 795-96, 804 (2010) ("[B]randing strategies make up a significant portion of general corporate strategy; financial analysts claim that brand equity makes up a tremendous amount of company value. At times, a company's brand equity has been more important than the book value ascribed to a particular product.").

28 See Marcum \& Perry, supra note 1, at 6.

29 See id. (noting that "[e]-commerce internet sites often have places for consumers to rate the products or leave other comments.").

30 See id. at 3 (discussing how Amazon is one of the "[c]ommon online venues" for posting reviews); see also About Customer Reviews, AMAZON.COM, https://www.amazon.com/ $\mathrm{gp} / \mathrm{help} /$ customer/display.html/ref=hp_left_v4_sib?ie=UTF8\&nodeId=201967050 (last visited Nov. 7, 2018) (indicating that customers may "submit written or video reviews for items" on the site).

31 See Bill Tancer, Everyone's a Critic: Winning Customers in a Review-Driven WORLD 7 (2014) (noting that "much of [Amazon's] success can be tied to the wealth of online opinions available to online shoppers.").

32 See Marcum \& Perry, supra note 1, at 62 (noting how social media has complicated "brand communication"); TANCER, supra note 31, at 19 ("Due to the explosion of social networks such as Facebook, niche networks dedicated to specific interests, and 140-character opinions of your business broadcast on Twitter, dissemination of consumer reviews are exploding ....."). 
independent review sites, including Angie's List, ${ }^{33}$ TripAdvisor, ${ }^{34}$ and perhaps most famously, Yelp. ${ }^{35}$ In the pre-internet age, disappointed customers could provide word-of-mouth criticism to family and friends. However, today's consumer has "the online equivalent of a bullhorn" and is thus able to disseminate criticism to millions of prospective customers. ${ }^{36}$

These consumer-review platforms have changed the historical scenario where the businesses themselves were the primary, widely-available sources of information about goods and services. Where once the businesses themselves pushed out information in the form of marketing, online reviews now provide a robust discussion of the products and services; a discussion that is largely outside of the companies' control. ${ }^{37}$ Thus, as Bill Tancer observes, "[f]or the first time in business history, aggregate opinions of quality can trump brand, marketing, and advertising spend." 38 Consumers are also increasingly relying on such independent online reviews. ${ }^{39}$ Recent statistics show that over $88 \%$ of online shoppers consult

33 See About Us, ANGIE's LIST, https://www.angieslist.com/aboutus.htm (last visited Nov. 7, 2018) ("Angie's List members submit more than 60,000 reviews every month about the companies they hire").

34 See About TripAdvisor, TRIPADVISOR, https://tripadvisor.mediaroom.com/us-about-us (last visited Nov. 7, 2018) (noting that TripAdvisor has approximately 661 million reviews of "7.7 million accommodations, airlines, experiences, and restaurants").

35 Yelp, founded in 2004, hosts online reviews for all types of businesses. About Us, YELP, https://www.yelp.com/about (last visited Nov. 7, 2018). As of the third quarter of 2017, it claimed to host over 142 million reviews, and to receive a monthly average of 104 million visitors to its site and mobile app. Id.; see also Ponte, supra note 4, at 62-63 (discussing "independent crowdsourced review sites, such as Yelp."); see also TANCER, supra note 31, at 9 ("The influence of online reviews expands beyond Web site commerce. National retailers, such as the cosmetic chain Sephora, have launched mobile applications to help consumers consult online reviews while in their physical stores. In fact, in addition to its mobile app, online review terminals appear in many of Sephora's stores, where consumers can read cosmetic reviews supplied by other customers to help them make informed purchase decisions.”).

36 TANCER, supra note 31 , at 27.

37 See Ponte, supra note 4, at 63 (discussing the "lively consumer dialogue in a variety of online sites outside the control of brand owners"); see also TANCER, supra note 31, at 20 ("If I were to sum up one of the chief concerns that businesses have about online reviews, it's the lack of control. There is a sense among most shop owners, specifically those in the hospitality industry (hotels, motels, restaurants, bars, cafés), that there is a strong causal link between their positive and negative reviews and the success or failure of their businesses.").

38 TANCER, supra note 31 , at 12 .

39 See Ponte, supra note 4, at 63 (discussing the "increased consumer reliance on online sources of product and service information-especially customer reviews"). 
internet reviews before making a purchase decision. ${ }^{40}$ The same percent of online shoppers (88\%) say that they trust online reviews as much as a personal recommendation from a friend or family member. ${ }^{41}$ Of course, to some extent, this is generational-younger shoppers tend, on average, to embrace online reviews more than older shoppers, who still often place greater trust in personal recommendations from relatives and friends. ${ }^{42}$ One problem with this reliance is that up to one-third of online reviews are believed to be fake. ${ }^{43}$ A specific study of Yelp estimated that up to $15 \%$ of Yelp reviews could be fake. ${ }^{44}$ In addition to fake reviews, other problems businesses encounter with online reviews include, but are not necessarily limited to: (1) businesses who pay customers (or complete strangers) to leave a good review, ${ }^{45}$ (2) customers who extort the business with a threat of a negative review unless some benefits are received, ${ }^{46}(3)$ review sites' (particularly Yelp's) alleged practices of conditioning the promotion of positive reviews (and the minimization of negative reviews) on whether the business purchases advertising from the review site, ${ }^{47}$ (4) being the type of business (such as a utility provider) where customers only think to

40 Khusbu Shrestha, 50 Important Stats You Need to Know About Online Reviews, VENDASTA BLOG (Aug. 29, 2016), https://www.vendasta.com/blog/50-stats-you-need-to-knowabout-online-reviews.

${ }^{41} \quad I d$.

42 See TANCER, supra note 31, at 9 ("A 2012 study by Bazaarvoice indicated that baby boomers prefer friend and family recommendations (66 percent) to online reviews (34 percent), while millennials (those born between 1977 and 1995) prefer online reviews (51 percent) to the opinion of friends and family (49 percent).”).

43 Ponte, supra note 4 , at 64.

44 Russell et al., supra note 5.

45 See TANCER, supra note 31, at 25 ("A visit to any city's Craigslist's online classifieds will yield listings such as the following: 'Yelp Reviews: looking for any Yelpers in good standing account to post reviews on businesses, if interested please provide a name[,] phone number[,] ant [sic] a link to your Yelp account. $\$ 25.00$ a review.”').

46 See id. at 26-28 (noting how one restaurant owner described the phenomenon to a newspaper food critic in San Francisco: “Customers have begun threatening to 'Yelp' the restaurant if their demands are not met. Cafe Rouge experienced this phenomenon twice within the past month when comps were demanded with the threat that a harsh review would follow on the Yelp website if we didn't comply. The expectation of how much to comp is also at issue, where a glass of wine, an appetizer or dessert no longer suffices.").

47 See id. at 29-33. (highlighting a representative complaint that alleged the following: "This company contacted me about reviews of my business on their website. They said they could 'help me improve my rating' if I were to spend $\$ 350$ a month in advertising. Since they are not the ones writing reviews, there is no way they could make this happen, unless they were to filter the bad reviews. I feel like I am being blackmailed.”). 
post reviews when bad things happen and thus the posted reviews are almost uniformly negative, ${ }^{48}$ and (5) reviews that are not relevant to the merchant's provision of goods or services (such as politically motivated reviews, or humorous reviews, or inability to get a reservation at a restaurant due to overwhelming popularity). ${ }^{49}$ Consumer reviews can also, of course, contain factual errors, omissions, or even differences of opinion. ${ }^{50}$ They are not perfect. Nevertheless, even though there must be some awareness by many consumers that some reviews may be inauthentic, inaccurate, or

48 Id. at 47 (discussing the situational bias around utility services that results in predominately negative reviews for these services).

49 Id. at 48-57. A pizza restaurant owner in Florida was photographed hugging President Barack Obama while he was running for reelection in 2012. The photo went viral, and was followed by hundreds of one-star reviews of the restaurant posted by conservative Republican voters, and 5-star reviews from left-leaning voters. $I d$. at 48. An example of a humorous review is one for the Hutzler 571 Banana Slicer, available for purchase on Amazon. One such review of the slicer provides as follows:

What can I say about the 571B Banana Slicer that hasn't already been said about the wheel, penicillin, or the iPhone. . . this is one of the greatest inventions of all time. My husband and I would argue constantly over who had to cut the day's banana slices. It's one of those chores NO ONE wants to do! You know, the old "I spent the entire day rearing OUR children, maybe YOU can pitch in a little and cut these bananas?" and of course, "You think I have the energy to slave over your damn bananas? I worked a 12 hour shift just to come home to THIS?!" These are the things that can destroy an entire relationship. It got to the point where our children could sense the tension. The minute I heard our 6-year-old girl in her bedroom, re-enacting our daily banana fight with her Barbie dolls, I knew we had to make a change. That's when I found the 571B Banana Slicer. Our marriage has never been healthier, AND we've even incorporated it into our lovemaking. THANKS 571B BANANA SLICER!

$I d$. at 50 . Another example of a review that is unrelated to the quality of a merchant is the following one-star restaurant review on Yelp:

This is my first review and felt compelled too [sic] because of my experience calling to make a reservation. How hard is it to call this place?! I have tried calling from 10am-1042am pacific time and all i [sic] get is a busy tone. And when i [sic] finally get through, they tell me they are fully booked and i [sic] need to be put on a wait list . . . UNBELIEVABLE. This after trying for 2 straight days! I will have to wait and see if I ever get a call back from the wait list. Good luck to those securing a reservation.

Id. at 61 . As Tancer points out, this reviewer gave the restaurant a negative one-star rating "simply because the restaurant is so popular that he can't get a reservation. From reading his short missive, you would assume that [the reviewer] has never eaten at The French Laundry, yet his one-star review factors into the restaurant's overall review rating." Id at 61-62. The restaurant in question, Tancer notes, "is one of the highest critically rated restaurants in the world," "has been named one of Restaurant Magazine's top fifty restaurants in the world," and was "declared the best restaurant in the world by the evercritical Anthony Bourdain." Id at 61.

$50 \quad I d$. at 6. 
contain other problems, consumers increasingly desire to communicate their experiences with each other and to obtain the benefit of others' prior experiences. ${ }^{51}$ Thus, as author Bill Tancer, in his book Everyone's a Critic, points out: "Today everything is reviewable: this book that you're reading right now, what you had for lunch yesterday, the café that you frequent most mornings, your dry cleaner, your doctor, your dentist, your blender, your professor, your favorite music, your date ... even you." 52

Because of the present ubiquity of online reviews, one study has estimated that American consumers engage in over 2 billion dialogues about merchants and their brands and reputations each day. ${ }^{53}$ Online reviews have become highly regarded by consumers since they make data available that gives purchasers some amount of assurance or confidence before deciding to make a purchase or enter into a contract. ${ }^{54}$ Moreover, as more consumers post their online reviews, and more consumers read and interact with them, the ongoing data exchange builds trust and facilitates additional purchases online.55 The reviews also increase consumers' power over the businesses they support. ${ }^{56}$

C. TYPES OF REVIEWERS AND REVIEWS: THE GOOD, THE BAD, AND THE UGLY

Businesses must deal with reviews, in some way or another. There are positive ones, which may indicate that the company is doing something right, and there are negative ones, which may indicate that the company is doing something wrong. There are also different motivations among those that post reviews online. Of

51 See Ponte, supra note 4, at 65 (citing BERGER, supra note 27, at 33-34) ("Neurological research indicates that 'self-sharing' activates the same pleasure sensors in our brain associated with food and money, so it may be difficult to dial back this desire in our social media age. About 87 percent of Americans use new media technologies, with about 86 percent preferring to interact with brands online.").

52 TANCER, supra note 31 , at 4.

$53 \quad I d$. at 12.

54 Id. at $4-5$.

55 Id. at 5 .

56 See Wayne Barnes, Social Media and the Rise in Consumer Bargaining Power, 14 U. PA. J. BUS. L. 661, 693 (2012) ("[U]se of the social media can greatly increase the consumer's bargaining power ....."); see also Marcum \& Perry, supra note 1 at 6 ("It "is clear that the 'power of the public' due to social media and the internet has created a defensive position by many businesses."). 
course, it is nearly impossible for a business to accurately predict what types of reviews and reviewers it will encounter. But the spectrum of possibilities is largely known or knowable. Here, I will briefly discuss the range of reviews that businesses receive and also the observed types of reviewers (or at least their apparent motivations). As will be shown, motivations range from benevolent to vicious.

First, it is interesting to note that the majority of consumers do not post online reviews. As of 2013, Bill Tancer states that only $11.2 \%$ of consumers (approximately 25.3 million in total) posted online reviews and ratings. ${ }^{57}$ Five years earlier, a 2008 study indicated that the percentage of consumers writing reviews was just $1 \%{ }^{58}$ Therefore, although $11.2 \%$ of the population is seemingly a small amount, the trajectory of the amount of those posting online reviews is trending upward-an increase of $1000 \%$ (or ten times) the amount of reviewers from 2008 to 2013.59 There is every reason to believe that the number of consumers posting reviews has only continued to increase. Nevertheless, the consumers who post are still a minority, albeit a vocal one. ${ }^{60}$

Of those consumers who do post online reviews, Tancer believes there are four "key reviewer archetypes" based on the reviewers' motivations for reviewing. ${ }^{61}$ The first archetype is the "communitarian." Communitarians are the most common type of online reviewer. ${ }^{62}$ Communitarians are motivated to participate in the online community of reviewers, much in the same way that people participate on social networks such as Facebook. ${ }^{63}$ Communitarians foster relationships with others participating on the review site. ${ }^{64}$ The second archetype is the "benevolent reviewer." 65 The benevolent reviewer is the "pleaser of the online world" and likes to help companies that give good service by

\footnotetext{
57 TANCER, supra note 31 , at 70.

$58 \quad I d$.

$59 \quad I d$.

60 Interestingly, Tancer observes that those earning over $\$ 150,000$ annually had a $95 \%$ greater likelihood than the general population to post reviews online. Id. at 74 .

61 Id. at 91.

$62 I d$.

$63 \quad I d$.

$64 \quad I d$.

$65 \quad I d$. at 92 .
} 
providing effusive reviews. ${ }^{66}$ The third archetype is the "status seeker." 67 Status seekers are competitive and strive to attain the high-volume statuses recognized by various sites, such as "Yelp Elite." 68 They could also be motivated by the perks that go with such status (such as attending events for elite reviewers). 69 The fourth archetype is the "one-star assassin."70 Tancer makes the following observations regarding one-star assassins:

This group is the most dreaded of all reviewer types. They're easy to spot when you look at their distribution of reviews. Typically they will have predominantly oneand two-star reviews, and a few five-star reviews. Interestingly, this archetype doesn't see the point of a three-star review.

Key motivation: As the name implies, this group isn't looking for a community; they don't want to make anyone happy, and status means little. They view online review sites simply as a platform to air their grievances. $^{71}$

There is usually no warning or indication as to when a one-star assassin will strike with a negative review; companies can only listen and try to rectify the perceived shortcoming if the complaint is valid. ${ }^{72}$

What types of reviews do consumers post? For purposes of this article, I focus on three types: positive reviews, negative reviews that are reasoned and factual, and extremely negative reviews that are more vitriolic or heated in tone. I discuss each below, along with examples and implications of each type.

\section{Positive Reviews}

Many online reviews are positive and praise a company for its goods or services. These present little concern, assuming that they

$66 \quad$ Id.

67 Id. at 93.

$68 I d$.

69 Id.

$70 \quad I d$. at 94 .

71 Id.

$72 \quad I d$. 
are genuine reviews posted by consumers who actually transacted with the reviewed merchant. A typical, glowingly positive review would be this review from a customer of a Four Seasons hotel location:

\section{Excellent stay}

We stayed with our children and everything was perfect. The children said upon arrival into the room, "I don't know how this day could get any better". The room was high quality. The staff recognized our children with personalized treats in the room, stuffed animals and child sized robes on the bed. Classic Four Seasons. We felt welcomed and relaxed. The hotel was beautifully decorated for the holidays. ${ }^{73}$

No business is likely to complain about receiving such an online review. Rather, this is what businesses hope for because it tells them they are providing good services or products, and it is likely to lead to additional business from future consumers. A Harvard Business School study conducted in 2011 concluded that a one star rating improvement on Yelp yielded anywhere from a 5\% to 9\% increase in revenues. ${ }^{74}$ Another study, led by a UC Berkeley professor, found that a mere "half-star" increase in a restaurant's Yelp rating translated to a 19\% increased chance of being full during top dining hours. ${ }^{75}$ This early research shows how crucial positive reviews can be to a business's revenue.

\section{Negative (but Factual) Reviews}

Businesses strive to avoid negative reviews because such reviews may reveal problems with their goods or services and give other consumers pause. Here is an example of a very negative, but

73 Susiefg, Excellent Stay: Review of Four Seasons Hotel Westlake Village, TRIPADVISOR.COM (Dec. 18, 2017), https://www.tripadvisor.com/ShowUserReviews-g33258d623631-r547884547-Four_Seasons_Hotel_Westlake_Village-Westlake_Village_ California.html\#CHECK_RATES_CONT.

74 Paresh Dave, Small Businesses Struggle To Manage Online Image, L.A. Times (Aug. 9, 2013, 7:05 PM), http://www.latimes.com/business/la-fi-tech-savvy-online-reviews-20130810story.html.

75 TANCER, supra note 31, at 11 (citing Michael Anderson \& Jeremy Magruder, Learning from the Crowd: Regression Discontinuity Estimates of the Effects of an Online Review Database, 122 The ECONOMIC J. 957 (2012)). 
purportedly factual, review received by a pizza restaurant in Boston:

Check out other reviews. They over charged my credit card by double. We ordered when we were staying at the plaza and everything else was cold. We got a buffy chicken calzone and fries. It took 90 minutes and everything arrived cold and tasted stale and old. They forced us to give a credit card \# even though we wanted to pay cash. They told me one cost on the phone but the actual charge on my credit card was double. If you quickly review other reviews you'll see other people had a similar experience. Be careful! ${ }^{76}$

As to negative reviews such as this one, there are upsides and downsides from the merchant's perspective. The upside is that the reviews may educate the merchant about issues with their goods or services and help them rectify or explain any issues that are causing customers to be disappointed. ${ }^{77}$ Another benefit is that some studies have shown that consumers have more confidence in positive reviews when the site or business also contains some negative reviews. ${ }^{78}$ Presumably, this makes the aggregate collection of reviews appear more authentic and credible. However, many businesses view the prospect of negative reviews in a far graver light, seeing them as "another perilous obstacle to their brand image

76 Richard K., Review of Regal Cafe (Feb. 24, 2016), https://www.yelp.com/biz/regal-cafeboston?hrid=CUV30pikFPY03uMwssqGdQ\&utm_campaign=www_review_share_popup\&ut m_medium=copy_link\&utm_source=(direct).

77 See TANCER, supra note 31, at 5 ("Consumers aren't the only ones who can benefit from reviews. Businesses have the opportunity to get in front of their prospective customers at the point when they're making purchase decisions."); see also Ponte, supra note 4, at 65 (noting that "increased interactivity has helped some businesses to gain valuable insight into the consumer experience"). Indeed, studies have shown that disappointed customers will often remove their negative online reviews if the company acts quickly to resolve the problem. Moreover, approximately 40 percent of customers would consider purchasing from the merchant again after critical online reviews are responded to in a timely fashion. $I d$. at 65 n. 15 (citing Kendall L. Short, Buy My Vote: Online Reviews for Sale, 15 VAND. J. ENT. \& TECH. L. 441, 451 (2013)).

78 See TANCER, supra note 31 , at 8 (" 68 percent of consumers trust reviews more when they see both negative and positive reviews on a site ...."). 
and business or professional success."79 A merchant's reputation in the relevant market is valuable but also vulnerable. ${ }^{80}$ And various statistics confirm the obvious-negative reviews can indeed be harmful. Some experts have posited that a single adverse review can reduce a business's revenue by $25 \% .{ }^{81}$ Therefore, the concern about negative online reviews is very real as the business's livelihood can be at stake.

The problem of negative reviews is particularly amplified as a challenge for businesses for several reasons. First, evidence shows that people are much more likely to use social media to share a negative customer service experience, as opposed to a positive experience. ${ }^{82}$ Second, studies show that consumers place greater emphasis on negative online reviews and remember them better than positive reviews. ${ }^{83}$ In fact, it seems as though the more negative the review, the more likely it will have a disproportionate impact: "For psychological reasons, angry online rants about products and services are more likely to tap into underlying hostilities and go viral more often than other shared emotions, such as sorrow or disappointment." 84

\section{Extremely Negative Reviews (Troll Alert!)}

There are negative reviews, and then there are really negative reviews. As Tancer notes, "[m]any business owners will attest that while most reviewers come to the experience with the altruistic goal

79 Ponte, supra note 4, at 65. Ponte arrives at this proposition after an exploration of several articles detailing the negative effects that online review websites can have on business growth and success. Id.

80 See Stefan Rutzel, Snitching for the Common Good: In Search of a Response to the Legal Problems Posed by Environmental Whistleblowing, 14 TEMP. ENVTL. L. \& TECH. J. 1, 36 (1995) ("Reputation and image are fragile commodities, and the public not always acts rationally in condemning activities.").

81 See, e.g., Dave, supra note 74.

82 See Eleanor Vaida Gerhards, Your Store is Gross! How Recent Cases, the FTC, and State Consumer Protection Laws Can Impact a Franchise System's Response to Negative, Defamatory, or Fake Reviews, 34 Franchise L. J. 503, 503 (2015) ("Online reviews drive business. They have a powerful, lasting impact but people are more likely to share their negative reviews. While 45 percent of people use social media to share bad customer service experiences, only 30 percent use social media to share good customer service experiences." (citations omitted)).

83 See Ponte, supra note 4, at 92 ("Because consumers tend to give greater weight to negative commentary and retain it better in their memories, businesses are concerned that even a few fake or real negative reviews will doom their future.").

84 Id. at 92 n.174 (citing BERGER, supra note 27, at 120). 
of sharing their honest opinion on a meal, stay, or product purchase, there's a darker and at times bizarre side to the economy of consumer participation." 85 These are the extreme version of the "one-star assassins" that Tancer discusses; consumers that go beyond describing factually what was wrong with their goods, services, or customer service, and post online reviews as a means to "air their grievances." 86 Businesses that have experienced online reviews are aware of this phenomenon. Many of them believe not only that disappointed consumers are more likely to post a review than satisfied consumers, but also that "unruly customers" are particularly likely to write a great number of the critical reviews of the business. ${ }^{87}$

Here is one example of such a review written by a customer at a Chicago-area McDonald's:

The worst McDonald's there is, ever was, and ever will be. It looks like a waiting room in purgatory, it smells like a taxi with a faint hint of bleach, and it tastes like they went rogue and started microwaving breakfast sandwiches from the freezer at Speedway.

I feel substantially worse about myself simply for having been here, and cannot shake the feeling that every good thing I've ever done in my life has just been canceled out.

Michael S. 88

Here is another McDonald's review, this time of a Minneapolis location:

Back in my very very broke days, I would eat here occasionally and spend literally a couple of dollars on something to get me by.

Everything was filthy. No one was nice. The food was awful. I think everyone should have this experience at

85 TANCER, supra note 31, at 24 (emphasis added).

86 Id. at 94 .

87 Id. at 28

88 Kate Taylor, The Most Horrifying Yelp Reviews of McDonald's Locations Across the US, Business INSIDER (Mar. 30, 2016, 12:10 PM), http://www.businessinsider.com/reviews-ofthe-worst-mcdonalds-2016-3. 
least once in their lives to show you how bad food can be.

Once you have experienced the lows, you will appreciate every other meal that much more for the rest of your life ... or perhaps you'll die from this one. That would be pretty unlucky, so try not to do that.

Ninja S. ${ }^{89}$

Of course, McDonald's is not the only merchant to receive these types of reviews. Here is a hotel review left by one patron on Yelp: "As for the spa, it is TOTALLY creepy and gross...but awesome! Definitely has a 1940s asylum vibe, with outmoded facilities and an air of decay. Sort of Scarlett O'Hara meets Nurse Ratched, ya know?? MUCH more interesting than some stupid fancy Vegas spa!"90

And here is one more representative review of this category, a review of a Boston pizzeria:

Oh my lord.

This is the worst place ever.

If you want to spend roughly 50 dollars to get a pie of pizza that looks like the inside of your brain the [sic] go ahead and go to this dump they call a "Pizzeria"

$--$

It took me for everyone [sic] get my slice. Around a hour.

Once I got the pizza I realized that my wings weren't there. I just said forget it. I took a look at my pizza and it looked terrible. But you know what they say "Don't judge a book by its cover"

$--$

So I took a bite of my zombie pizza. And when I tell you it tastes like ass it tastes like ass. Immediately after eating that nonsense I threw up faster then Sonic the Hedgehog.

$89 \quad I d$.

90 Anna Merlan, 'Large Blood Stain on Carpet:' The Bleakest Motel Reviews on Yelp, JEZEBEL (Mar. 12, 2015, 2:30 PM), https://jezebel.com/large-blood-stain-on-carpet-thebleakest-motel-reviews-1690817925. 
I called back the place and this guy said "DJDMEKDTKDJDN" then hangs up.

This place must be burned.

Edit!

Calling back they make this old computer sound effects so :^|91

Of course, many more examples could be given. These "one-star assassins" obviously go beyond what is necessary to reasonably describe the factual shortcomings that they perceived (if there were any such shortcomings at all). In an article titled "8 Types of Trip Advisor Reviews You Should Totally Ignore," Roger Wade describes recurring categories of these reviews. ${ }^{92}$ One type described is "Avoid this hotel at all costs!"93 Wade notes that "a trolling review like this almost certainly results from a single incident where the guest didn't get his or her way." 94 A related type of review is described as "The worst hotel I've ever stayed in!" 55 Wade remarks about this type of review:

This is another common trolling technique where the reviewer is filled with rage and trying to put the hotel out of business with a few hyperbolic paragraphs. For one thing, how do I know the types of hotels you have stayed in before? If you are a Saudi prince you might say that the Abu Dhabi Four Seasons is the worst hotel you've stayed in, even though I'd love it.

But again, as long as this one-star review is nearly alone among a sea of 3-, 4-, and 5-star reviews, a review like this might actually say more about the poor hotelchoosing skills of its writer than about the hotel itself.

91 Rebel Taxi N., YeLP (June 25, 2016), https://www.yelp.com/biz/regal-cafeboston?hrid=dpMGl6t2xUJ62g0FphJ8vQ\&utm_campaign=www_review_share_popup\&utm _medium=copy_link\&utm_source=(direct).

92 See Roger Wade, 8 Types of TripAdvisor Reviews You Should Completely Ignore, PRICEOFTRAVEL.COM (July 8, 2013), https://www.priceoftravel.com/3650/8-types-oftripadvisor-reviews-you-should-completely-ignore/ (explaining how to distinguish useful online reviews from those with "personal ax[es] to grind.").

$93 \quad I d$.

$94 \quad I d$.

$95 \quad I d$. 
Or more likely, this person is just a jerk who loves to complain and wants to be heard by anyone who will listen. ${ }^{96}$

Yet another type of review Wade counsels to avoid on TripAdvisor is " Everything was filthy!' (when no one else mentions it). ${ }^{\prime 97}$ Wade analyzes these types of review as follows:

More than likely, these reviews are left by someone who was displeased by something else entirely, but explaining that would make them sound too selfish or unreasonable so they decided instead to vent by calling the place "filthy." Either that, or these reviewers are suffering from some disorder and probably should never leave the house. ${ }^{98}$

One more type of review category observed by Wade is "[t]he staff are all extremely rude!' 99 Wade notes that the likelihood that the entire staff of a hotel are all rude is fairly small; what such a review more likely suggests is that the guest demanded some perk or benefit above and beyond what was paid for and then characterized them simply as rude when he or she did not get it. ${ }^{100}$

Why do consumers post online reviews like these, that in their vitriolic hyperbole go far beyond what is reasonably necessary to describe the actual, specific problems or deficiencies that they encountered? One recent study analyzed narrative framing of consumer opinions contained in restaurant reviews posted online. ${ }^{101}$ The authors of the study hypothesize that online reviews "are fundamentally a kind of social discourse, in which reviewers employ narratives to portray their own social or psychological characteristics, role or stance.”102 The authors focused, among other

96 Id.

97 Id.

$98 \quad I d$.

99 Id.

100 Id.

101 Dan Jurafsky, Victor Chahuneau, Bryan R. Routledge, \& Noah A. Smith, Narrative Framing of Consumer Sentiment in Online Restaurant Reviews, 19 FIRST MONDAY No. 4 (2014).

102 Id. at 2. 
things, on the type of narrative framing in very negative online reviews. They initially observed that "[o]ne hypothesis might be that there is no characteristic framing, that negative reviews merely consist of descriptions of food with negative evaluative vocabulary." 103 That is not, however, what they found to be the case. Instead, the authors observed that negative online restaurant reviews tend to be emotion-based, about bad things that were perceived to have happened to them; commonly used words included "worst, rude, terrible, horrible, bad, awful, disgusting, bland, tasteless, gross, mediocre, overpriced, worse, poor," coupled with framing in the first-person. ${ }^{104}$ These are the same types of features, the authors observed, that are associated with people's expressions of trauma. Based on this, the authors conclude the following: "The similarity of one-star reviews to the linguistic characteristics of these trauma narratives suggests a hypothesis that negative restaurant reviews are not simply reviews describing bad food, but rather are trauma narratives, a coping mechanism for dealing with the minor trauma people experience at the restaurants." 105

In short, some consumers use online reviews as a vehicle for expressing trauma in the form of an overly negative review, regardless of how disproportionate or commensurate such framing is when viewed in the context and perspective of a consumer transaction.

There is, of course, a simpler explanation-some people just act like trolls on the internet. A recent article by Joel Stein in Time, titled "How Trolls Are Ruining the Internet," describes the phenomenon in broad terms. ${ }^{106}$ Stein introduces his article by stating of trolls: "They're turning the web into a cesspool of aggression and violence." 107 He elaborated in his introduction:

[T] he Internet's personality has changed. Once it was a geek with lofty ideals about the free flow of information.

\footnotetext{
$103 \quad I d$. at 6.

104 Id.

105 Id. at 7 (citing James W. Pennebaker \& Kent D. Harber, A Social Stage Model of Collective Coping: The Loma Prieta Earthquake and the Persian Gulf War, 49 J. OF SocIAL ISSUES 125 (1993)).

106 Joel Stein, How Trolls Are Ruining the Internet, TIME (Aug. 18, 2016), http://time.com/4457110/internet-trolls/.

107 Id.
} 
Now, if you need help improving your upload speeds the web is eager to help with technical details, but if you tell it you're struggling with depression it will try to goad you into killing yourself. Psychologists call this the online disinhibition effect, in which factors like anonymity, invisibility, a lack of authority and not communicating in real time strip away the mores society spent millennia building. And it's seeping from our smartphones into every aspect of our lives. ${ }^{108}$

As Stein notes, "[t]he people who relish this online freedom are called trolls." 109 Internet trolls pervade all types of venues online. They go to Facebook pages of people who recently died and ridicule their deaths. ${ }^{110}$ They threaten death or rape to public figures with whom they disagree; sometimes, they threaten to rape 5-year old daughters of people with whom they disagree. ${ }^{111}$ Trolls participate in and sometimes overrun websites, especially in the comment sections, with their negative commentary. ${ }^{112}$ An anonymous poll of writers at Time established that almost half of the female journalists had considered quitting because of vicious online attacks (although no male journalists had considered quitting). ${ }^{113}$ Some entertainment figures have quit social media at times because of abusive, trolling behavior, including Kanye West, Adele, and Justin Bieber. ${ }^{114}$ It seems that "troll culture" is a problem on the internet, and, as Stein states, it is "affecting the way nontrolls treat one another." 115 According to a study by UC Irvine professor Zeev Kain, people that were exposed to good actions on Facebook were $10 \%$

\footnotetext{
108 Id.

109 Id. The term "trolls" is one that "originally came from a fishing method online thieves use to find victims. It quickly morphed to refer to the monsters who hide in darkness and threaten people. Internet trolls have a manifesto of sorts, which states that they are doing it for the 'lulz,' or the laughs." Id.

110 Id.

111 Id.

$112 I d$. ("When sites are overrun by trolls, they drown out the voices of women, ethnic and religious minorities, gays-anyone who might feel vulnerable.").

114 Ian J. Stark, Celebrities Who've Quit Social Media: Kanye West, Adele, Justin Bieber, More, NEwSDAY (Feb. 15, 2018, 1:10 PM), https://www.newsday.com/entertainment/ celebrities/celebrities-who-ve-quit-social-media-kanye-west-adele-justin-bieber-more1.12706108 .

115 Stein, supra note 106.
} 
more likely to claim doing such good deed themselves, but the converse also may be happening. ${ }^{116}$ Trolling behavior therefore seems to be a genuine problem in the culture of the Internet, and it appears to feed on itself.

Obviously, this article is not equating fiercely negative online reviews of goods or services with sending death or rape threats to celebrities or journalists. However, it does seem to be part of the dark side of internet culture that has been evolving for some time. In 2004, John Suler discussed the term-the online disinhibition effect-that explained this behavior:

Everyday users on the Internet-as well as clinicians and researchers-have noted how people say and do things in cyberspace that they wouldn't ordinarily say and do in the face-to-face world. They loosen up, feel less restrained, and express themselves more openly. So pervasive is the phenomenon that a term has surfaced for it: the online disinhibition effect. ${ }^{117}$

Suler notes that sometimes the reduced inhibition can result in neutral or even positive behavior, such as sharing personal information or emotions, and doing kind and generous acts. ${ }^{118} \mathrm{He}$ called this behavior "benign disinhibition."119

But, sometimes the behavior is darker: "We witness rude language, harsh criticisms, anger, hatred, even threats." 120 Suler called this "toxic disinhibition."121 Suler observed several underlying reasons for the phenomenon of the online disinhibition effect including the following: (1) dissociative anonymity (being anonymous online reduces the sense of vulnerability about communicating, since the anonymity precludes the communications from affecting their real "offline" lives); (2) invisibility (physical invisibility emboldens those online, since they are not physically

\footnotetext{
$116 \quad I d$.

117 John Suler, The Online Disinhibition Effect, 7 CyberPsychol. \& Behav. 321, 321 (2004).

118 See id. (noting people "reveal secret emotions, fears, and wishes and "sometimes [go] out of their way to help others.").

$119 I d$.

120 Id.

121 Id.
} 
seen and cannot physically see others' physical reactions-e.g., frowning, head-shaking, sighing, etc.-which might otherwise inhibit the communication); (3) asynchronicity (the fact that communication is asynchronous- "[p]eople don't interact with each other in real time"-and that you do not have to deal with any instant reaction, lowers inhibitions); and (4) minimization of status and authority (the absence of obvious physical authority figures online tends to lower inhibitions to speak). ${ }^{122}$

The bottom line, of course, is that the internet has a tendency to cause people to behave worse online than how they act in person. ${ }^{123}$ And, it is quite reasonable to suppose that this tendency, this online disinhibition effect, results in some consumers posting online reviews that go beyond a straight-forward description of perceived problems and deficiencies in goods or services and into a gratuitous, hyperbolic, vicious rant about the goods, services, or the merchant itself. As Suler indicated, persons participating online, including in vitriolic online reviews, may feel that there are no consequences or checks on their behavior. ${ }^{124}$ However, the consequences to businesses can be very real. Sue Gratton, a Canadian lawyer currently heading a project in Ontario to deal with the problem of online reviews, correctly notes: "negative online reviews can be devastating to reputation . . . internet speech is instantaneous, it has global reach, it can be easily forwarded or hyperlinked, it can be anonymous and it is certainly very difficult to get rid of." 125 The advent of the internet gives new weight to the saying, "a lie can travel halfway around the world while the truth is putting on its shoes." 126 And the speed with which such reviews travels is exacerbated when it goes beyond the scope of a factual,

122 Id. at 322-24.

123 See Mark Manson, Why Everyone on the Internet is an Asshole, MARKMANSON.NET (August 15, 2013), https://markmanson.net/internet (explaining how the "internet has a way of bringing out the worst in people.").

124 See Suler, supra note 117, and accompanying text.

125 Rosa Marchitelli, 'A Year and a Half of Hell': Customers, Businesses Pay Price for Online Reviews, CBC NEws (Oct. 26, 2017, 4:47 PM), http://www.cbc.ca/news/business/go-publiconline-reviews-lawsuit-backlash-1.4369246.

126 This quote has been attributed to many, including Mark Twain and Winston Churchill, although the apparent origin is of some dispute. A Lie Can Travel Halfway Around the World While the Truth Is Putting on Its Shoes, QUOTE INVESTIGATOR, https://quoteinvestigator.com/2014/07/13/truth/\#note-9363-13 (last visited Nov. 7, 2018). 
demonstrative review and instead seemingly attempts to destroy the business in a single post.

\section{MERCHANTS STRIKE BACK: THE RISE OF THE NON-DISPARAGEMENT CLAUSE}

In the face of negative online reviews posted by consumers, and the threat such reviews posed to businesses' reputations and viability, many merchants began to include non-disparagement clauses in their consumer contract terms to contractually prohibit the consumer from posting negative online reviews. ${ }^{127}$ Parties have long used other types of "contracts of silence" or confidentiality in other contexts with few problems of enforceability. ${ }^{128}$ These include categories of "speech suppression agreements in employment, settlement, franchise, and personal relationship situations."129 These contracts have long been upheld based on longstanding notions of freedom of contract and the principle that parties have an opportunity to read the contract before signing and are thus generally bound by its contents-i.e. the "duty to read." 130 In these other contexts, the clauses are also often seen as furthering some separate legal right or obligation, "such as the protection of trade secrets and other intellectual property, the confidentiality of employer-employee and other fiduciary relationships, the preservation of individual privacy, or the nondisclosure of national security concerns."131

\footnotetext{
127 See Michaela Marx Wheatley, Non-disparagement Clauses May Cause Businesses More Trouble Than They Are Worth, THE OKLAHOMAN (June 24, 2015, 9:38 AM), http://newsok.com/article/5429125 (noting that more businesses are adding nondisparagement clauses to their sales agreements).

128 Ponte, supra note 4, at 71.

129 Id. at 72 (citing Alan E. Garfield, Promises of Silence: Contract Law and Freedom of Speech, 83 CoRnell L. ReV. 261, 268-74 (1998); Can Nondisparagement Clauses Silence Negative Online Reviews?, THE LEGAL INTELligencer (June 26, 2014), http://www.blankrome.com/index.cfm?contentID=37\&itemID=3352).

130 Id. (citing Omri Ben-Shahar, The Myth of the "Opportunity to Read" in Contract Law, 27 Eur. Rev. Cont. L. 1, 2-3 (2009); Richard E. Speidel, Unconscionability, Assent and Consumer Protection, 31 U. PITT. L. REv. 359, 364, 375 (1970); Daniel E. Ho, Fudging the Nudge: Information Disclosure and Restaurant Grading, 122 YALE L.J. 574, 578-79 (2012); Lucille M. Ponte, Getting a Bad Rap? Unconscionability in Clickwrap Dispute Resolution Clauses and a Proposal for Improving the Quality of These Online Consumer "Products", 26 OHIo ST. J. ON DiSP. RESOL. 119, 159-67 (2011)).

131 Id. (citations omitted).
} 
Based on the longstanding enforceability of non-disparagement clauses in these other contexts and notions of freedom of contract generally, businesses presumably thought that insisting on these non-disparagement clauses (or, as Eric Goldman calls them, "antireview" clauses) ${ }^{132}$ was within their prerogative as a matter of private ordering. However, these tended to be met with various amounts of resistance from both the courts of law and popular opinion as will be demonstrated below.

One early case dealing with use of a type of clause prohibiting reviews was People $v$. Network Associates, Inc. ${ }^{133}$ In that case, a software company placed provisions in its software license that forbade users of the software from the publication of any test results or reviews of the software without the company's prior permission. ${ }^{134}$ Notably, the restrictive clause provided that the "rules and regulations" of installing the program prohibit publishing reviews without permission. ${ }^{135}$ An internet magazine sought permission and was denied but posted a negative review anyway. ${ }^{136}$ The software company sent correspondence to the magazine, voicing its concerns based on the publication of reviews in violation of the license's restrictive clause; shortly thereafter, the state attorney general's office began investigating the issue. ${ }^{137}$ The court concluded that the clause was deceptive under New York law

132 Eric Goldman, Understanding the Consumer Review Fairness Act of 2016, 24 MicH. Telecom. \& TeCH. L. Rev. 1, 1 (2017). "Another synonym is 'gag clause.' The term 'nondisparagement clause' is also used, but some anti-review clauses restrict all consumer reviews, even reviews that are not disparaging." Id. at 1 n.2 (citing H.R. REP. NO. 114-731 at 5 (2016)).

133758 N.Y.S.2d 466 (N.Y. Sup. Ct. 2003).

134 Id. at 467. The restrictive clause provided as follows:

Installing this software constitutes acceptance of the terms and conditions of the license agreement in the box. Please read the license agreement before installation. Other rules and regulations of installing the software are:

a. The product cannot be rented, loaned, or leased-you are the sole owner of this product.

b. The customer shall not disclose the result of any benchmark test to any third party without Network Associates' prior written approval.

c. The customer will not publish reviews of this product with-out prior

$I d$. consent from Network Associates, Inc.

135 Id.

$136 \quad I d$.

137 Id. 
based on the potential for consumers to be misled that the "rules and regulations" language was not merely private contractual language but rather an independent command of state or federal law. ${ }^{138}$ This case has been cited for the proposition that a contract clause forbidding online reviews is generally a deceptive practice. ${ }^{139}$ However, this particular case actually stood for the proposition that a company, if it chose to include a clause prohibiting reviews, should do so in a way that does not mislead consumers into believing it is an independent "rule or regulation" under state or federal law. ${ }^{140}$

At one point, non-disparagement clauses were also used by medical professionals to keep patients from posting negative reviews. ${ }^{141}$ A company called Medical Justice was especially influential in this area as it marketed form contracts to medical professionals that included clauses prohibiting patient reviews. ${ }^{142}$ The contract forms varied in their approach over time with some including a straightforward ban on reviews while others included an assignment of any ownership rights in reviews to be posted by the patient in the future. ${ }^{143}$ The Medical Justice contract forms became popular for a time-as many as 2,000 medical providers used the forms, and approximately one million Americans signed at least one of the forms. ${ }^{144}$ Due to some negative publicity, as well as

138 Id. at 469.

139 See, e.g., Goldman, supra note 132, at 8 ("Anti-review clauses also violate consumer protection laws. For example, in People v. Network Associates, a New York lower court held that an anti-review clause in a software end-user license agreement (EULA) violated New York's consumer protection law.").

140 See Ponte, supra note 4, at 74 ("[T]he decision did not invalidate all confidentiality clauses preventing consumer speech---only deceptive ones.”); Genelle I. Belmas and Brian N. Larson, Clicking Away Your Speech Rights: The Enforceability of Gagwrap Licenses, 12 COMM. L. \& POL'Y 37, 42 (2007) ("The New York court enjoined the use of the gagwrap provision not because of its content but because of the arguably deceptive way in which it was presented.”); Jennifer Chandler, Information Security, Contract And Liability, 84 CHI.-KENT L. REV. 841, 845 (2010) ("Unfortunately, the New York Supreme Court did not actually rule on whether anti-benchmarking provisions are contrary to public policy or not. Instead, the ruling was quite narrow and stated only that the particular provision in this case was deceptive.").

141 See Goldman, supra note 132, at 2 ("Anti-review clauses initially found the widest deployment in the healthcare field.”).

$142 I d$.

143 Id. (citing The Back Dtory, DoctoredReviews.com, https://doctoredreviews.com/patients/the-back-story/ (last visited Oct. 5, 2018)).

144 Id. at 3 (citing Letter from Angie Hicks to S. Comm. on Com., Sci. \& Transp. (Nov. 3, 2015), http://www.angieslist.com/news-releases/angie-hicks-letter-us-senate-committee commerce-science-transportation-re-consumer/; Eric Goldman, Fining Customers For 
litigation against one medical provider seeking to enforce the form, Medical Justice ceased using the forms containing the clauses prohibiting reviews. ${ }^{145}$

A few other high-profile situations of consumers being pursued for violation of non-disparagement clauses drew the attention of the public and of legal observers. One involved a vacation rental dispute where the rental agreement required the tenants to "agree not to use blogs or websites for complaints, anonymously or not." 146 The tenants posted negative reviews that violated the clause (though they had not noticed it beforehand), and the property owners filed suit for breach of contract, defamation, and other legal theories. ${ }^{147}$ The court dismissed all causes of action except the breach of contract action, which survived based on the clear language of the non-disparagement clause. ${ }^{148}$ Other similar vacation rental disputes have drawn attention, such as that of Tom and Terri Dorow, whose credit card was charged $\$ 500$ after they posted a negative review in violation of the non-disparagement clause in their rental contract. 149 The Dorows eventually agreed to remove their review in exchange for a refund of the $\$ 500$ charge but were unhappy about the experience (and talked about their unhappiness in the media). ${ }^{150}$

Other merchants have been reported to use non-disparagement clauses, almost always being highlighted in the media in an unfavorable fashion. For example, an upstate New York hotel, the Union Street Guest House, included the following contract language for all hotel guests:

Negative Online Reviews Isn't New...Or Smart, FoRBEs TerTIUM QuID (Aug. 7, 2014, 10:47 AM), http://www.forbes.com/sites/ericgoldman/2014/08/07/fining-customers-for-negativeonline- reviews-isnt-new-or-smart/).

145 See id. (citing Eric Goldman, Medical Justice Capitulates by "Retiring" Its Anti-Patient Review Contracts, TECH. \& MARKETING L. BLOG (Dec. 1, 2011), http://blog.ericgoldman.org/archives/2011/12/medical_justice.htm) ("Medical Justice eventually reversed course and started evangelizing consumer reviews...")).

146 Galland v. Johnston, No. 14-CV-4411, 2015 WL 1290775, at*1 (S.D.N.Y. Mar. 19, 2015).

147 Id. at *2.

148 Id. at *7.

149 Christopher Elliott, New Confidentiality Clauses Can Influence Vacation Rental Reviews, ELLIOTT.ORG (Apr. 14, 2012), http://elliott.org/blog/new-confidentiality-clauses-caninfluence-vacation-rental-reviews/.

$150 I d$. (quoting Dorow as saying "We feel that we should be able to post an accurate accounting of what we experienced, which did not match what they advertised on the VRBO site"). 
If you have booked the Inn for a wedding or other type of event anywhere in the region and given us a deposit of any kind for guests to stay at USGH there will be a $\$ 500$ fine that will be deducted from your deposit for every negative review of USGH placed on any internet site by anyone in your party and/or attending your wedding or event. If you stay here to attend a wedding anywhere in the area and leave us a negative review on any internet site you agree to a $\$ 500$ fine for each negative review. ${ }^{151}$

The response to the hotel's policy was overwhelmingly negative and resulted in many negative reviews posted on Yelp and elsewhere-including by many who did not even stay at the hotel. ${ }^{152}$

A Florida apartment complex upped the ante-it imposed a ban on all negative reviews or commentary, including on Facebook or other social media, and provided for a $\$ 10,000$ fine for any violation of the terms. ${ }^{153}$ The terms also assigned ownership of any writings or photos "regarding the Owner, the Unit, the property, or the apartments" to the apartment complex. ${ }^{154}$ The rental contract included a paragraph explaining the owner's rationale:

There is a growing trend ... where tenants will post unjustified and defamatory reviews regarding an apartment complex in an attempt to negotiate lower rent payments, or otherwise seek concessions from a landlord. Such postings can cripple a business by creating a false impression in the eyes of consumers. The damages resulting from this false impression can include potentially millions of dollars in economic

\footnotetext{
151 Jayson DeMers, How One Hotel Ruined Its Reputation By Penalizing Negative Reviews, FORBES (Nov. 3, 2014, 12:01 PM), https://www.forbes.com/sites/jaysondemers/ 2014/11/03/how-one-hotel-ruined-its-reputation-by-penalizing-negativereviews/\#4918dbf94806.

152 See id. ("Partly in retaliation and partly in a protest against the policy, hundreds of reviewers posted negative reviews against the hotel, driving its Yelp rating down to a lousy one-and-a-half stars.").

153 Joe Mullin, One Apartment Complex's Rule: You Write a Bad Review, We Fine You \$10k, ARS TECHNICA (Mar. 10, 2015, 9:28 AM), http://arstechnica.com/tech-policy/2015/03/oneapartment-complexs-rule-you-write-a-bad-review-we-fine-you-10k/.

$154 I d$.
} 
losses, and have permanent consequences that can unjustly destroy a business. ${ }^{155}$

It appears that the policy was abandoned by subsequent management, but not after being criticized in the public and by respectable legal experts in the field. ${ }^{156}$

Another noteworthy case involved a Texas couple, the Duchouquettes, who hired Prestigious Pets to watch and feed their dog and fish while they were away. ${ }^{157}$ The pet care contract contained a non-disparagement clause, but the couple nevertheless posted a negative review when they were unhappy with the service. ${ }^{158}$ Prestigious Pets filed a lawsuit against the Duchouquettes, claiming breach of contract and damages of up to $\$ 1$ million for lost business and profits. ${ }^{159}$ The lawsuit was dismissed based on the Texas Anti-SLAPP statute, but the case gained a lot of publicity in the media. ${ }^{160}$

Perhaps the incident that has garnered the most publicity involved online retailer KlearGear.com, ${ }^{161}$ who used a nondisparagement clause coupled with a $\$ 3,500$ liquidated damages clause, in their online terms of service. ${ }^{162}$ Consumers could only view the clause after clicking three levels deep into their online terms. ${ }^{163}$ John Palmer unknowingly agreed to the terms when he purchased a $\$ 20$ keychain on the KlearGear.com website. ${ }^{164}$ Jen Kulas, John's wife, wrote a negative online review about the

155 Id.

156 Id. Professor Eric Goldman is quoted in the article: "It would be a terrible idea to enforce this in court. A judge is going to shred it . . . . If a person posts an Instragram [sic] photo of them having a party in their apartment, the landlord is saying they own that as well. The overreach reinforces that this clause is bad news, and it may be actionable just to ask." Id.

157 Claire Z. Cardona, \$1M Lawsuit Dismissed Against Plano Couple Who Gave 1-Star Yelp Review to Pet-Sitting Company, Dallas Morning News (Aug. 30, 2016), https://www.dallasnews.com/news/courts/2016/08/30/1m-lawsuit-plano-couple-one-star-yelpreview-dismissed.

158 Id.

159 Id.

160 Id. ("The Duchouquettes argued the case should be dismissed based on the Texas AntiSLAPP statute, meant to allow judges to dismiss frivolous suits filed against people who speak out about a matter of public concern.”).

161 Goldman, supra note 132, at 4.

162 Daniel D. Barnhizer, Escaping Toxic Contracts: How We Have Lost the War on Assent in Wrap Contracts, 44 SW. L. REV. 215, 225 (2014).

163 Id.

$164 I d$. 
transaction, which prompted KlearGear to demand payment of $\$ 3,500$ in liquidated damages. KlearGear ultimately referred the matter to a collection agency and reported the amount as a delinquent debt on Palmer's credit report. ${ }^{165}$ The couple responded by filing a lawsuit against KlearGear and recovered a default judgment in the amount of $\$ 306,750 .{ }^{166}$ In an e-mail to the media, Vic Mathieu, the director of corporate communications for KlearGear's Paris-based corporate parent (DBS) stated the following:

[Palmer was] belligerent toward our customer care staff and threatened to defame KlearGear if he did not receive free merchandise and other consideration.

Such a customer behavior is rare, but it has become an increasing problem for many companies today . . . DBS' head of retail for North America . . . cites this problem as one of the reasons that we started to eliminate Kleargear.com's social media channels in $2012 .{ }^{167}$

Notwithstanding KlearGear's public stance, the reports in the media were overwhelmingly negative. ${ }^{168}$ And, in what appears to be a PR maneuver, KlearGear has apparently disappeared in name from the internet, changing its name to "Epic Giftables."169 Presumably, the company is trying to distance itself from the reputational damage caused by the incident.

\section{THE CONSUMER REVIEW FAIRNESS ACT}

In response to the increased use of non-disparagement clauses, Congress intervened by generally outlawing the practice of using

\footnotetext{
165 Cyrus Farivar, KlearGear Must Pay $\$ 306,750$ to Couple that Left Negative Review, ARS TECHNICA (June 25, 2014, 8:10 PM), http://arstechnica.com/tech-policy/2014/06/kleargearmust-pay-306750-to-couple-that-left-negative-review.

166 Barnhizer, supra note 162, at 225.

167 Farivar, supra note 165.

168 Id.; Eugene Volokh, Default Judgment Against KlearGear, the Company that Billed Customers for $\$ 3,500$, because They Posted a Negative Review, THE VOLOKH CONSPIRACY (May 16, 2014).

169 Entering "KlearGear.com" into a web browser redirects to www.epicgiftables.com (last visited Jan. 12, 2018).
} 
the clauses to prevent honest reviews of goods or services. On December 15, 2016, President Obama signed into law H.R. 5111, known as the Consumer Review Fairness Act (CRFA). ${ }^{170}$ The preamble to the law states that it is designed to prohibit some types of form contract clauses that limit consumers' rights to engage in communication regarding goods or services purchased in interstate commerce. ${ }^{171}$ I will now discuss the text of the Act, followed by a discussion of its operation in current practice. While the CRFA prohibits a clause that globally disallows reviews, it is not absolute and some types of reviews may still be contractually prohibited.

\section{A. THE TEXT OF THE ACT}

Subsection (a) of the CRFA provides the applicable definitions for the Act. Two definitions are critical. The first is "covered communication," which the Act defines as "a written, oral, or pictorial review, performance assessment of, or other similar analysis of, including by electronic means, the goods, services, or conduct of a person by an individual who is party to a form contract with respect to which such person is also a party." 172

The term covers virtually any type of consumer review that exists today, whether online or in more traditional "offline" media (although the online variety is the primary target).

The second critical definition of the CRFA is "form contract," since the Act only covers consumers who are bound by such agreements. "Form contract" means a contract with "standardized terms" used by the merchant, and to which a consumer consents "without a meaningful opportunity for such individual to negotiate the standardized terms." 173 Of course, consumers often agree to form contracts by merely clicking their assent when making a purchase online, ${ }^{174}$ so the form contract provision will not be a significant

\footnotetext{
170 Andrew Tarantola, President Obama Signs the Consumer Review Fairness Act into Law, ENGADGET (Dec. 15, 2016), https://www.engadget.com/2016/12/15/president-obama-signsthe-consumer-review-fairness-act-into-law/.

171 Consumer Review Fairness Act of 2016, Pub. L. No. 114-258 (2016) (codified at 15 U.S.C. $\S 45 b)$.

17215 U.S.C. $\S 45 b(a)(2)$ (Supp. IV 2016).

${ }^{173}$ Id. § 45b(a)(3) (Supp. IV 2016).

174 Barnes, supra 56, at 663-64 ("[In the last several decades] the use of form contracts has only increased, especially with online contract terms-such as website terms of use and software license agreements - to which consumers assent by use of 'clickwrap' or
} 
limitation on the wide-ranging application of the CRFA. Some have speculated that merchants could seek to avoid application of the CRFA by allowing individualized negotiation or the chance to "optout" of a non-disparagement clause. ${ }^{175}$ However, this is unlikely to work because the CRFA states that a "form contract" is one where the consumer lacks opportunity to negotiate "the standardized terms"-as in, all boilerplate language, not just a nondisparagement clause specifically. ${ }^{176}$ In other words, unless a merchant allows meaningful opportunity to negotiate the entire set of boilerplate terms (e.g., warranty terms, remedies terms, etc.)-a highly unlikely scenario-then the contract likely remains a "form contract" under the CRFA, and the Act remains applicable.

Subsection (b) of the CRFA provides, "except as provided in paragraphs (2) and (3)," a form contract provision is void if the clause does one of the following: (1) denies or limits the ability to "engage in a covered communication" (basically if it prevents posting reviews), (2) purports to charge a penalty or fee for "engaging in a covered communication," or (3) assigns intellectual property rights in any posted reviews. ${ }^{177}$ Thus, the CRFA seemingly imposes a straightforward ban on contract clauses preventing consumer reviews, whether through a clause that states reviews may not be posted, a clause that imposes a penalty for such reviews, or a clause that purports to transfer intellectual property rights in any posted reviews. The end result is that consumers can feel at liberty to post reviews of goods or services, irrespective of any contract provision purporting to limit their ability to do so.

However, the CRFA includes several limitations to its applicability. One is that, because of an exception to the definition

\footnotetext{
'browsewrap.' Robert Hillman and Jeffrey Rachlinski noted that '[t]he Internet is turning the process of contracting on its head.' Thus, consumers are assenting to form contracts in everincreasing amounts, especially online, with the ease of a mouse click (or tablet screen tap)." (citing Russell Korobkin, Bounded Rationality, Standard Form Contracts, and Unconscionability, 70 U. CHI. L. REV. 1203, 1203 (2003); Robert A. Hillman \& Jeffrey J. Rachlinski, Standard-Form Contracting in the Electronic Age, 77 N.Y.U. L. REV. 429, 431 (2002); Wayne R. Barnes, Toward a Fairer Model of Consumer Assent to Standard Form Contracts: In Defense of Restatement Subsection 211(3), 82 WASH. L. REV. 227, 229 (2007))).

175 See Goldman, supra note 132, at 11-12 (citing Brian A. Berkley, Can Opt-Out Provisions Save Arbitration Clauses?, LAW360 (June 8, 2016), http://www.foxrothschild.com/ publications/can-opt-out-provisions-save-arbitration-clauses/).

17615 U.S.C. $\S 45 b(a)(3)(A)(i i)$ (Supp. IV 2016).

177 Id. $\S 45 \mathrm{~b}(\mathrm{~b})(1)$ (Supp. IV 2016) (emphasis added).
} 
of "form contract," the Act does not apply to contracts between either an employer and employee, or between a principal and an independent contractor. ${ }^{178} \mathrm{~A}$ second set of provisions state that the CRFA is not to be construed to affect any of the following:

(A) any duty of confidentiality imposed by law (including agency guidance);

(B) any civil cause of action for defamation, libel, or slander, or any similar cause of action;

(C) any party's right to remove or refuse to display publicly on an Internet website or webpage owned, operated, or otherwise controlled by such party any content of a covered communication that-

(i) contains the personal information or likeness of another person, or is libelous, harassing, abusive, obscene, vulgar, sexually explicit, or is inappropriate with respect to race, gender, sexuality, ethnicity, or other intrinsic characteristic;

(ii) is unrelated to the goods or services offered by or available at such party's Internet website or webpage; or

(iii) is clearly false or misleading; or (D) a party's right to establish terms and conditions with respect to the creation of photographs or video of such party's property when those photographs or video . . . are created by an employee or independent contractor of a commercial entity and solely intended for commercial purposes by that entity. ${ }^{179}$

Moreover, a third set of provisions state another series of exceptions to the CRFA. Those provisions state that the CRFA does not disallow a form contract clause that prohibits disclosure or submission of several types of information, including: (1) "trade secrets or confidential commercial information," (2) private personnel or medical files, (3) information assembled for "law enforcement purposes," (4) "content that is unlawful or otherwise

178 Id. $\S 45 \mathrm{~b}(\mathrm{a})(3)(\mathrm{B})$ (Supp. IV 2016).

179 Id. $\S 45 \mathrm{~b}(\mathrm{~b})(2)$ (Supp. IV 2016) (emphasis added). 
meets the requirements of paragraph (2)(C)," and (5) malicious computer code including viruses and the like. ${ }^{180}$

The enforcement provisions of the CRFA state that it shall be "unlawful" to include a form contract provision that violates the Act. ${ }^{181}$ A violation of the CRFA is an unfair or deceptive act or practice under the Federal Trade Commission Act (FTC Act) and is enforceable by the Federal Trade Commission. ${ }^{182}$ The CRFA also provides for potential enforcement by state attorneys general. ${ }^{183}$ FTC violations are generally administratively enforceable by the FTC but not by way of a private cause of action. ${ }^{184}$ However, by declaring a CRFA violation to be unlawful under the FTC Act, violations likely become actionable under many state statutes. ${ }^{185}$

\section{B. THE EFFECT OF THE CRFA ON CURRENT PRACTICE}

The CRFA appears to put an immediate stop to any attempt by merchants to implement a contract provision that provides a wholesale prohibition on consumer reviews. An attempt by merchants to ban any and all negative reviews, described in the previous section, is terminated on a nationwide basis as a matter of federal law. The underlying rationale of the CRFA is to maintain the flow of information currently emanating from the everincreasing amount of consumer reviews, such that consumers can continue "to rely on them more heavily as credible indicators of product or service quality." 186 And the CRFA will accomplish this for the great majority of scenarios. There are certainly policy arguments that could be made in favor of allowing merchants the freedom of contract to protect their interests with a non-

180 Id. $\S 45 \mathrm{~b}(\mathrm{~b})(3)(\mathrm{A})-(\mathrm{E})$ (Supp. IV 2016).

181 Id. $\S 45 b(c)$ (Supp. IV 2016).

182 Id. § 45b(d) (Supp. IV 2016).

183 Id. § 45b(e) (Supp. IV 2016).

184 See Stephanie L. Kroeze, The FTC Won't Let Me Be: The Need for a Private Right of Action Under Section 5 of the FTC Act, 50 VAL. U. L. REV. 227, 227-28 (2015) ("[One] cannot allege a Section 5 violation of the Federal Trade Commission Act ("FTC Act"), which prohibits the deceptive acts of companies, because she is a private consumer.").

185 See Goldman, supra note 132, at 7 (stating that "[w]hile the implications of the 'unlawful' declaration are unclear for federal law, it's clear that an unlawful contract clause creates various state law claims" and providing examples from California and New Jersey).

186 H. R. REP. No. 114-731 at 5 (2016). 
disparagement clause. ${ }^{187}$ Negative reviews can be very harmful to a business, and thus it is understandable why some businesses have previously tried to limit the harm to their livelihood. ${ }^{188}$ We currently allow merchants to contractually protect other interests without a federal ban forbidding them from doing so-e.g., warranty disclaimers, ${ }^{189}$ limitations on remedies, ${ }^{190}$ and arbitration clauses, ${ }^{191}$ just to name a few. However, in the case of the CRFA, the political verdict seems to be in. The CRFA was passed with overwhelming bipartisan support, demonstrating that the desire to preserve consumers' rights to post reviews (and continuing the data flow available to all consumers created by such reviews) is strong indeed and that, in a sense, the primary debate is over. ${ }^{192}$

But what about the trolls? Does the CRFA render merchants powerless to defend themselves? In a word, no. The CRFA emphatically does not put American businesses completely at the mercy of online reviews, and, specifically, the trolls. Recall, for our present purposes, that the Act does not apply to a form contract clause which prohibits submission of, among other things, "content that is unlawful or otherwise meets the requirements of paragraph 2(C)."193 In other words, merchants may still include a provision that prohibits certain kinds of reviews.

\footnotetext{
187 See Barnes, supra note 56, at 661-62 ("The consumer is legally bound by the terms contained in the form contract, because, in theory, he has a duty (and is able) to read the contract, could have done so if he had desired, and ultimately indicated his assent to the form by signing, clicking, or otherwise outwardly manifesting his assent to the form contract's terms.").

188 See generally supra notes 73-84 and accompanying text; see also Franklin G. Snyder \& Ann B. Mirabito, The Death of Contracts, 52 DuQ. L. REv. 345, 395 (2014)

Today, ubiquitous ratings systems on popular web sites, sometimes with free and open (and often virulent) commentary, allow individual consumers to extract a measure of vengeance on the businesses that they believe have wronged them. Contracting parties who once were able to view each customer as an isolated transaction, and who saw the harm of dissatisfaction as limited, now face a world in which a handful of disgruntled consumers can seriously affect their reputations and their businesses.

189 U.C.C. § 2-316 (AM LAW INST. \& UNIF. LAW COMM'N 1977).

190 U.C.C. § 2-719 (AM LAW INST. \& UNIF. LAW COMM'N 1977).

1919 U.S.C. $\S \S 1-16(2012)$.

192 See Press Release, U.S. Senate Committee on Commerce, Science \& Transportation, Senate Sends Legislation Protecting Consumer Reviews to President (Nov. 28, 2016), https://www.commerce.senate.gov/public/index.cfm/2016/11/senate-sends-legislationprotecting-consumer-reviews-to-president (noting that the CRFA bill passed in the Senate by unanimous vote).

19315 U.S.C. $\S 45 b(b)(3)(D)$ (Supp IV. 2016) (emphasis added).
} 
What kinds of reviews can still be contractually banned, postCRFA? First, content that is "unlawful" can be prohibited by a consumer form contract. ${ }^{194}$ Although the CRFA does not define "unlawful," the Act states that its provisions do not affect (among other things) causes of action for "defamation, libel, or slander, or any similar cause of action." 195 Therefore, a form contract may almost certainly under the CRFA permissibly preclude a consumer from posting any online review that is defamatory under principles of tort law. ${ }^{196}$ Thus, consumers who post negative reviews that are false, or who post reviews when in fact they never purchased goods or services from the merchant in the first place, should clearly be targetable by such a clause. Some are concerned about the in terrorem effects of being able to contractually prohibit that which is already prohibited in tort, since consumers and others may give undue effect to such a clause, and due to the fact that whether something is ultimately defamatory is often strongly disputed. ${ }^{197}$ However, the question is one of degrees. Even without a contract provision, threats to sue based on defamation may readily be made and such claims still subject the consumer to legal peril. 198

Second, the CRFA provides that merchants may still include clauses that prohibit submission of content that "otherwise meets the requirements of paragraph $(2)(\mathrm{C})$. " 199 Paragraph $(2)(\mathrm{C})$, in turn, refers to reviews or other content that is, among other things, "libelous, harassing, [or] abusive," that is "unrelated to the goods or services" in question, or that is "clearly false or misleading." ${ }^{200}$ Some of these provisions overlap with the prior provisions on defamation, but some are conceptually distinct. Of particular importance to the present subject is paragraph $(2)(\mathrm{C})$ 's reference to "abusive" content.

194 Id.

195 Id. $\S 45 \mathrm{~b}(\mathrm{~b})(2)(\mathrm{B})$.

196 See Goldman, supra note 132, at 2 ("The CRFA says . . . its restrictions don't apply to 'content that is unlawful.' Arguably, 'defamatory' content is 'unlawful.' That means businesses probably can contractually restrict consumers from posting 'defamatory' reviews without violating the CRFA.").

197 See id. (noting that "defamation is a legal conclusion that is often hotly contested").

198 See id. (discussing how "businesses can spuriously claim that a review is defamatory and then take one of the actions otherwise prohibited by the CRFA, i.e. threaten to sue consumers for contract breach, impose a fine/penalty on the consumer, or send copyright takedown notices").

19915 U.S.C. $\S 45 b(b)(3)(D)$ (Supp. IV. 2016).

200 Id. $\S 45 \mathrm{~b}(\mathrm{~b})(2)(\mathrm{C})$ (Supp. IV. 2016) (emphasis added). 
It is important to note that "abusive" is stated separately in the provision from "libelous"-accordingly, Congress' contemplation of "abusive" reviews must mean reviews that are not necessarily defamatory or libelous. ${ }^{201}$ And, in fact, many online reviews are couched in terms of exaggerated opinion, or what may be characterized as "rhetorical hyperbole." 202 Such published statements are typically not found to be defamatory, thus Congress likely saw a need for the additional categories in paragraph (2)(C). This is almost certainly because Congress was mindful of the nature of certain types of communication on the internet. ${ }^{203}$ Exaggerated, hyperbolic, virulent speech is increasingly common online, no less so than in online consumer reviews, as described previously. ${ }^{204}$

The term "abusive" is not defined in the CRFA. ${ }^{205}$ One dictionary definition of "abusive" is "using, containing, or characterized by harshly or coarsely insulting language." 206 This sounds a lot like the trolling internet behavior discussed previously, and the extremely negative reviews in particular. ${ }^{207}$ Recall that John Suler described "toxic disinhibition" in online internet behavior thusly: "We witness rude language, harsh criticisms, anger, hatred, even threats." 208 And statistics show that in the context of online reviews, 30\% of consumers post reviews to express negative emotions and $23 \%$ post

\footnotetext{
201 See 82 C.J.S. Statutes $§ 386$ (2018) ("It is a cardinal principle of statutory construction that a statute ought, upon the whole, to be so construed that if it can be prevented, no clause, sentence, or word is superfluous, surplusage, nugatory, void, meaningless, or insignificant.”).

202 See Rodney A. Smolla, 1 LaW of Defamation $\S \S 4: 11-4: 12$ (2d. ed.) ("The use of 'rhetorical statements [involves] employing 'loose, figurative, or hyperbolic language'. . . . [such statements are generally] immune from attack for defamation under both the common law and constitutional doctrines that prohibit opinion from forming the basis of a defamation suit.").

203 See Jessica Bennett, OMG! The Hyperbole of Internet-Speak, N.Y. Times (Nov. 28, 2015), www.nytimes.com/2015/11/29/fashion/death-by-internet-hyperbole-literally-dying-over-thiscolumn.html (describing how communication on the internet tends to be hyperbolic and very emotional).

204 See supra Part I.C.3 (discussing the rationale behind negative reviews).

205 See 15 U.S.C. $§ 45 \mathrm{~b}(\mathrm{a})$ (including no definition for the word "abusive").

206 Abusive, DICTIONARY.COM, http://www.dictionary.com/browse/abusive (last visited Jan. 13, 2018).

207 See supra notes 85-126 and accompanying text.

208 See Suler, supra note 124, at 321.
} 
purely for vengeance. ${ }^{209}$ It seems that the toxicity Suler described can and does reach the realm of consumer online reviews.

This all sounds like a recipe for abusive behavior. Business can no longer ban consumers' honest, factual reviews, whether positive or negative; must they also tolerate the reviews that rise to a toxic or "abusive" level? The CRFA says they need not. Of course, if defamation is hotly contested, then whether an online review is "abusive" is surely to be the subject of considerable dispute. Some amount of color to an opinion should be allowed, but when consumers go far beyond the factual accounting needed to express the rationale for their displeasure ("the steak was tough" or "the shower was mildewy and there was no hot water"), and gratuitously pile on with their opinion ("THIS FOOD IS THE WORST! IT TASTES LIKE PIG VOMIT!") surely the point of abusiveness is being approached. Contrary to popular opinion, businesses should not be forced to accept whatever abusive commentary their customers foist on them online. And surely Congress considered the nature of abusive internet commentary-i.e. trolling-when they included the "abusive" provision of paragraph $(2)(\mathrm{C})$. Thus, under the CRFA, trolls may troll, but they do so at their own peril if a merchant decides to contractually ban the practice. ${ }^{210}$

\section{ADDRESSING OBJECTIONS TO THIS ARTICLE'S STATUTORY ANALYSIS OF CFRA}

Professor Eric Goldman has voiced a strong rebuke of this article's statutory analysis that merchants are permitted under the CRFA to ban abusive reviews of their goods and services (albeit they

\footnotetext{
209 Luke Brynley-Jones, A Statistical Insight into Online Customer Complaints, OURSOCIALTIMES.COM, http://oursocialtimes.com/23-of-people-complain-online-out-ofvengence/ (last visited Jan. 13, 2018).

210 One issue I will not look at in depth at this point, but at least wish to mention here, is whether the continued use of any such express non-disparagement clauses implicate any constitutional freedom of speech concerns. Scholars are divided on the issue, although the sounder approach seems to be that notions of freedom of contract and consensual formation of voluntary agreements overcome any constitutional issues, including the likely lack of any state action involved in enforcing a purely private, consensual agreement between private parties (and waiver of such constitutional rights even in the event state action is found). See Ponte, supra note 4, at 114-15 (citing Garfield, supra note 129, at 348-49; Belmas \& Larson, supra note 140, at 67-69) (noting that freedom of contract allows individuals to waive their "legal rights of speech"). The constitutional issue will be discussed infra, Part III.C.
} 
are no longer permitted to generally ban all honest reviews). ${ }^{211} \mathrm{I}$ believe Goldman's analysis is well-meaning, but clearly incorrect. I address his arguments below and explain why they do not change this Article's conclusions regarding the CRFA.

\section{Statutory Provisions at Issue}

Before addressing Goldman's flawed arguments, it is helpful to set up the discussion with a more complete quotation of the relevant CRFA provisions. Subsection (b)(1) contains the CRFA's general prohibition of form contract provisions restricting the ability to engage in "covered communications" (i.e., reviews of goods or services). ${ }^{212}$ Importantly, subsection (b)(1)'s provision provides that it is subject to exceptions under "paragraphs (2) and (3)." 213 The meaning and import of these exceptions is critical to the analysis and thesis of this article that merchants may contractually ban abusive reviews. Paragraph (2), labeled "Rule of construction," provides the following in full:

(2) Rule of construction. Nothing in paragraph (1) shall be construed to affect-

(A) any duty of confidentiality imposed by law (including agency guidance);

(B) any civil cause of action for defamation, libel, or slander, or any similar cause of action;

(C) any party's right to remove or refuse to display publicly on an Internet website or webpage owned, operated, or otherwise controlled by such party any content of a covered communication that-

(i) contains the personal information or likeness of another person, or is libelous, harassing, abusive, obscene, vulgar, sexually explicit, or is inappropriate with respect to race, gender, sexuality, ethnicity, or other intrinsic characteristic;

\footnotetext{
211 See Eric Goldman, Businesses Cannot Contractually Ban "Abusive" Consumer Reviews, TECH. AND MKTG. LAW BLOG (July 17, 2018), https://blog.ericgoldman.org/ archives/2018/07/businesses-cannot-contractually-ban-abusive-consumer-reviews.htm (arguing that my statutory analysis is incorrect and that contractual bans of abusive reviews are illegal).

21215 U.S.C. $\S 45 b(a)-(b)$ (Supp. IV. 2016).

213 Id. $\S 45 \mathrm{~b}(\mathrm{~b})(1)$ (Supp. IV. 2016).
} 
(ii) is unrelated to the goods or services offered by or available at such party's Internet website or webpage; or

(iii) is clearly false or misleading; or

(D) a party's right to establish terms and conditions with respect to the creation of photographs or video of such party's property when those photographs or video are created by an employee or independent contractor of a commercial entity and solely intended for commercial purposes by that entity. ${ }^{214}$

Notice the emphasis on Paragraph (2)(C) above. In this subsection, Paragraph (2)(C) clearly is addressing the rights of those who maintain a website or internet presence-like Yelp, Amazon, TripAdvisor, or even a particular merchant who houses reviews on its own website-to refuse to display various types of reviews (including those that are abusive). Notice two things about Paragraph 2(C): (1) who-it addresses who has rights to remove or refuse to display certain categories of reviews on its website (companies that host reviews), and (2) what - the actual categories of reviews that are excludable (abusive, harassing, libelous, vulgar, etc.). Paragraph (3), labeled "Exceptions," provides the following in full:

(3) Exceptions. Paragraph (1) shall not apply to the extent that a provision of a form contract prohibits disclosure or submission of, or reserves the right of a person or business that hosts online consumer reviews or comments to remove-

(A) trade secrets or commercial or financial information obtained from a person and considered privileged or confidential;

(B) personnel and medical files and similar information the disclosure of which would constitute a clearly unwarranted invasion of personal privacy;

(C) records or information compiled for law enforcement purposes, the disclosure of which would constitute a clearly unwarranted invasion of personal privacy;

${ }_{214}$ Id. $\S 45 \mathrm{~b}(\mathrm{~b})(2)$ (Supp. IV. 2016) (emphasis added). 
(D) content that is unlawful or otherwise meets the requirements of paragraph $(2)(C)$; or

(E) content that contains any computer viruses, worms, or other potentially damaging computer code, processes, programs, applications, or files. ${ }^{215}$

Of course, Paragraph (3)(D) is pivotal to my analysis. Paragraph (3)(D) provides that the primary CRFA prohibition of Paragraph 1 shall not apply "to the extent that a provision of a form contract prohibits disclosure or submission of ... content that is unlawful or otherwise meets the requirements of paragraph (2)(C)." ${ }^{16}$ Since one of the "requirements" of Paragraph (2)(C) is that the review be "abusive,"217 Paragraph (3)(D) seems to plainly allow a form contract provision that bans abusive reviews.

\section{Goldman's Arguments}

Goldman strenuously argues that this plain text interpretation is incorrect. ${ }^{218} \mathrm{He}$ makes five specific arguments, each of which will be addressed here. However, his overarching argument is that Paragraph $(2)(\mathrm{C})$ is only limited to "consumer review services" (i.e., those hosting reviews on their own website), and thus the reference in Paragraph (3)(D) to Paragraph (2)(C) is similarly limited only to "consumer review services" like Yelp, and is not available for regular, non-review-hosting-businesses to use in their form contract provisions with their customers (like hotels, retailers, etc.). ${ }^{219}$

However, his reading is erronous. Paragraph 3's preamble refers to two types of provisions: (1) a provision that "prohibits disclosure or submission of" certain content 220 and (2) a provision that "reserves the right of a person or business that hosts online consumer reviews or comments to remove" certain content. ${ }^{221}$ That Paragraph (3) refers to both of these scenarios is borne out by the use of the conjunctive "or" in its preamble.

\footnotetext{
215 Id. $\S 45 \mathrm{~b}(\mathrm{~b})(3)$ (Supp. IV. 2016) (emphasis added).

216 Id.

217 Id. $\S 45 \mathrm{~b}(\mathrm{~b})(2)(\mathrm{C})(\mathrm{i})$ (Supp. IV. 2016).

218 Goldman, supra note 211.

219 Id.

22015 U.S.C. $§ 45 b(b)(3)$ (Supp. IV. 2016).

221 Id.
} 
The second category above seems to clearly refer to "consumer review services" companies like Yelp, in that it refers to a business that "hosts online consumer reviews." 222 Since the Paragraph 3 preamble refers (in its second category) to a business that "reserves the right ... [in hosting] online consumer reviews to remove [certain reviews]," 223 it is superfluous to read the reference to Paragraph (2)(C) to also include Paragraph (2)(C)'s preamble relating to "any party's right to remove or refuse to display publicly on an Internet website or webpage owned, operated, or otherwise controlled by such party." 224 The two preambles (the second category of Paragraph (3) and the only category of Paragraph (2)(C)) both address the same type of business-one that hosts reviews, such as Yelp. So, if Paragraph (3)(D)'s reference to Paragraph (2)(C) carries with it the who of Paragraph (2)(C), and not just the what, it would be redundant. Here is a paraphrased reading: "Paragraph (1) shall not apply to the extent that a provision of a form contract . . . reserves the right of a person or business that hosts online consumer reviews . . to remove ... (D) [provisions that] a party has a right to remove from an Internet website or webpage owned . . by such party . . . including abusive reviews. . . ." The successive italicized provisions above are redundant and superfluous. The reference to Paragraph $(2)(\mathrm{C})$ should thus be read to only import the what (i.e., Paragraph (2)(C)'s roman-numeral subdivisions), not the who (the reference to consumer review-hosting businesses).

Further, if the second category of business referred to in the Paragraph (3) preamble is "consumer review services" like Yelp, then what is the first category of business it refers to? The first category in Paragraph (3) simply refers to "a provision of a form contract [that] prohibits disclosure or submission of . . (D) content that ... meets the requirements of paragraph (2)(C) [which includes abusive reviews]." 225 Since this is a different category, it must refer to businesses other than "consumer review services." If Paragraph (3)(D) is limited to the who preamble limitation of Paragraph (2)(C), then it becomes at least partially superfluous. Therefore, the first category of Paragraph (3)(D) refers, in a word, to ordinary

222 Id.

223 Id.

$224 \quad$ Id. $\S 45 \mathrm{~b}(\mathrm{~b})(2)(\mathrm{C})$.

$225 \quad I d . \S 45 \mathrm{~b}(\mathrm{~b})(3)$. 
businesses (like retailers, hotels, medical professionals, etc.) which place form provisions in their contracts. And, the reference to Paragraph 2(C) does not necessarily require importing the Paragraph $(2)(\mathrm{C})$ preamble of the who (since, as noted above, that would result in superfluity), but rather only the what - in this case (among other things) abusive reviews.

Here, quickly, are Goldman's five specific buttressing arguments. As I demonstrate, none of them changes the fatal flaw that underlies the entire argument:

a. "Submission" only applies to consumer review services

Goldman says that the "submission" verb in Paragraph (3)(D) "clearly applies only to consumer review services (or businesses running their own review function)." ${ }^{226} \mathrm{He}$ further states that "[i]t's nonsensical for the provision to restrict 'submissions' of reviews to third parties." 227 I am not claiming the latter, as previously discussed. However, "submission" can be read to apply to consumers posting reviews of their merchants on third-party sites like Yelp or TripAdvisor. Included in the dictionary definitions of "submit" are: "to present or propose to another for review, consideration, or decision; to put forward as an opinion or contention." ${ }^{228}$ Clearly, when a customer posts a review on TripAdvisor describing their experiences at a hotel, she is "submitting" it for the world to see. ${ }^{229}$ Goldman's argument here is unavailing.

b. A consumer review is not a "disclosure"

Similarly, Goldman argues that "characterizing a consumer review as a 'disclosure' would be bizarre." 230 This may be true, but it overlooks the fact that Congress used the phrase "prohibits disclosure or submission" and then referred to various categories: trade secrets, personnel and medical files, law enforcement

\footnotetext{
226 Goldman, supra note 211.

227 Id.

228 Definition of Submit, MERRIAM-WEBSTER, https://www.merriamwebster.com/dictionary/submit.

${ }_{229}$ This is further supported by the fact that TripAdvisor refers to reviews as submissions. TRIPADVISOR, TripAdvisor's Content Policy, https://www.tripadvisorsupport.com/hc/enus/articles/360008133913-TripAdvisor-s-Content-Policy (last visited Nov. 7, 2018) ("We only publish content submitted by travelers 13 or older.”)

230 Goldman, supra note 211.
} 
information, the Paragraph (2)(C) categories (including abusive reviews), and computer viruses, etc. ${ }^{231}$ The word "disclosure" works for some of these, and the word "submission" works for others. Therefore, the word "submission" covers the posting of abusive reviews-consumers "submit" reviews for posting on Yelp, TripAdvisor, etc. ${ }^{232}$ Goldman's argument here is unavailing.

c. The word "abusive" is constrained by the introductory language in the Paragraph (2)(C) exclusion

Next, Goldman argues that "the word 'abusive' is constrained by the introductory language in the Paragraph $(2)(\mathrm{C})$ exclusion, which expressly applies only to a website or webpage 'owned, operated, or otherwise controlled' by the party." ${ }^{233}$ For Goldman's argument to be correct, one would have to read Paragraph (3)(D) as follows (in rough paraphrased form): It shall be unlawful for review-hosting businesses to have form contracts that prohibit disclosure or submission of . . (D) clauses that review-hosting businesses have a right to refuse to display, including . . . abusive reviews. There is no need for the successive italicized clauses-reading the statute in the way that Goldman argues is redundant and superfluous. The reference here to Paragraph $(2)(\mathrm{C})$ is only referencing the what of that provision (i.e., categories of content), not the who (reviewhosting businesses). Otherwise, the statute is needlessly superfluous, which is to be avoided in matters of statutory interpretation. ${ }^{234}$

d. Paragraph $(2)(C)$ 's limitation to consumer review services means that Paragraph (3)(D) is so limited

Goldman next argues that the Paragraph (2)(C) exclusion only applies to the "right to remove or refuse to display publicly" on a website or webpage owned by the party, and that this only applies to review-hosting websites like Yelp or TripAdvisor. ${ }^{235}$ While this may be true, that again only applies to the who of Paragraph $(2)(\mathrm{C})$, not the what. And Paragraph (3) is not so limited, as has been

\footnotetext{
$231 \quad 15$ U.S.C. $\S 45 \mathrm{~b}(\mathrm{~b})(3)$ (emphasis added).

232 TRIPADVISOR, supra note 229.

233 Goldman, supra note 211.

234 Statutes, supra note 201.

235 Goldman, supra note 211.
} 
argued above. This is just a re-assertion of Goldman's primary argument, but it renders Paragraph (3)(D) a superfluity.

e. Is "abusive content" grammatically incorrect?

Finally, Goldman simply states that "the phrase 'abusive content,' as opposed to abusive 'behavior," is not grammatically correct. ${ }^{236}$ This is a frivolous argument. For one, the first dictionary definitions of "abusive" in Merriam-Webster dictionary are: "(a) using harsh, insulting language, [as in] an angry and abusive crowd; (b) harsh and insulting, [as in] abusive language."237 Further, the statute itself contemplates "abusive" language. Paragraph (2)(C) provides that the CRFA does not affect a website's right to refuse to display "any content of a covered communication that . . . is . . . abusive" (among many other categories of content). ${ }^{238}$

3. Goldman's arguments Run Afoul of the Federal Trade Commission Guidance and Other Interpretations of CRFA

Further reinforcing that this Article's interpretation of the CRFA is correct-and that Goldman's argument is flawed-is the Federal Trade Commission's guidance regarding the CRFA. On the FTC webpage entitled "Consumer Review Fairness Act: What Businesses Need to Know," the FTC gives a concise overview of the CRFA for the guidance of businesses across the country. ${ }^{239}$ Notably, the website does not purport to address only "review-hosting businesses" like Yelp and TripAdvisor. It is addressed to all businesses. In a section labeled "What Can A Company Do to Protect Itself from Inappropriate or Irrelevant Content?”, the FTC provides the following:

The law says it's OK to prohibit or remove a review that:

1. contains confidential or private information-for example, a person's financial, medical, or personnel file information or a company's trade secrets; 
2. is libelous, harassing, abusive, obscene, vulgar, sexually explicit, or is inappropriate with respect to race, gender, sexuality, ethnicity, or other intrinsic characteristic;

3 . is unrelated to the company's products or services; or

4 . is clearly false or misleading.

However, it's unlikely that a consumer's assessment or opinion with which you disagree meets the "clearly false or misleading" standard. ${ }^{240}$

As demonstrated above, the FTC website agrees with this Article's straightforward interpretation of the CRFA. The statute allows businesses to ban abusive reviews.

Nor is the FTC website the only public interpretation which agrees with this Article's conclusion that the CRFA facially allows businesses to ban abusive reviews. Professor Eugene Volokh, in discussing the CRFA's potential constitutionality, interpreted the CRFA in the same manner as this Article. ${ }^{241}$ Although Volokh contends that the CRFA may run afoul of the free speech protections of the First Amendment, there is no doubt that he agrees with this Article's conclusion of the facial CRFA provisions. Volokh correctly interprets the statute as providing that the CRFA prohibits businesses from banning most reviews but does allow the banning of certain types of reviews, including abusive ones. Many other commentators, law firms, bloggers, and industry associations have also reached this conclusion, often relying on the guidance provided by the FTC. ${ }^{242}$ This is the plain meaning of the CRFA and the

240 Id. (emphasis added).

241 See Eugene Volokh, Congress to Allow Special Restrictions on Speech 'Inappropriate with Respect to Race, Gender, Sexuality, Ethnicity, or Other Intrinsic Characteristic??, THE VOLOKH CONSPIRACY (Sept. 13, 2016), https://www.washingtonpost.com/news/volokhconspiracy/wp/2016/09/13/congress-to-allow-special-restrictions-on-speech-inappropriatewith-respect-to-race-gender-sexuality-ethnicity-or-other-intrinsic-

characteristic/?utm_term=.a0bde8195f6c (noting that the CRFA exempts certain types of contracts including those that contain abusive language).

242 See Drake Forester, The Consumer Review Fairness Act \& What It Means for Your Business, SCORE (Sept. 18, 2017), https://www.score.org/blog/consumer-review-fairness-actwhat-it-means-your-business; Robert Darwell \& Cameron Mabrie, Consumer Review Fairness Act's Point of "No Return," Covering Your ADS Blog (Apr. 17, 2017), https://www.coveringyourads.com/2017/04/articles/consumer-protection/consumer-reviewfairness-acts-point-of-no-return/; Jason J. Kim, How Companies Can Comply with the Newly 
Paragraph (3)(D) exception. Congress obviously did not intend for businesses to be completely hobbled in protecting themselves against abusive, troll-like behavior of unscrupulous internet reviewers.

\section{ONE CAUTION—DIVERGENT STATE LAWS}

As discussed above, the CRFA allows merchants to ban online reviews that are defamatory and abusive. However, one complicating aspect is the presence of state laws also targeting nondisparagement clauses that do not contain the CRFA's allowance for limited bans. Congress could have chosen to occupy the field and assert supremacy over conflicting state law, but the CRFA expressly allows states to pass their own laws on the subject as they see fit. ${ }^{243}$

Two states, California and Maryland, had passed laws addressing non-disparagement clauses prior to the CRFA. California's law bans any consumer contract provision that prohibits the consumer from making "any statement regarding the seller or lessor or its employees or agents, or concerning the goods

Effective Consumer Review Fairness Act, Hunton ReTail Law Resource (Mar. 24, 2017), https://www.huntonretailindustryblog.com/2017/03/articles/consumer-protection/companiescan-comply-newly-effective-consumer-review-fairness-act/; Cynthia Conlin, What Is The Consumer Review Fairness Act?, CYNTHIA CONLIN \& Associates (May 6, 2017), http://conlinpa.com/2017/05/06/consumer-review-fairness-act/; Laura A. Brenner, Troy A. Hilliard, \& Jeffrey D. Roeske, Let Thy Consumer Review: Gag Clauses Outlawed in Form Contracts, ReINHART, BoERner, VAN DEuren, S.C. (May 19, 2017), https://www.reinhartlaw.com/knowledge/let-thy-consumer-review-gag-clauses-outlawed-inform-contracts/; The Truth Will Set You Free: The FTC Provides New Guidance on Consumer Reviews, ADVERTISING LAW ALERTS (Mar. 8, 2017), http://fkks.com/news/the-truth-will-setyou-free-the-ftc-provides-new-guidance-on-consumer-revie; New Federal Law Prohibits NonDisparagement Provisions in Form Contracts, COOLEY (Jan. 18, 2017), https://www.cooley.com/news/insight/2017/2017-01-18-new-federal-law-prohibits-nondisparagement-provisions-in-form-contracts; Joseph Sullivan, Compliance Update: The Consumer Review Fairness Act, GA. Restaurant Ass'N: GRA Blog (Mar. 30, 2018), https://www.garestaurants.org/gra-blog/compliance-update-the-consumer-review-fairnessact; Colleen Lopez, Disparaging Reviews and Social Media Posts, The DuBoff LAW GrouP (July 27, 2018), https://www.dubofflaw.com/disparaging-reviews-social-media-posts/; David Lazarus, He Wanted Jewish, Liberal and not so Tall. The Dating Service Gave him Some, not all. Then the Yelp War Began, L.A. Times (Apr. 21, 2017), http://www.latimes.com/business/lazarus/la-fi-lazarus-dating-service-20170421-story.html; Daniel Batterman, Muzzling the Muzzlers: The Consumer Review Fairness Act, SASOON \& CYMroT (Feb. 1, 2018), https://www.sassooncymrot.com/news/test-post1/ (concluding that abusive reviews are exempt from the CRFA).

24315 U.S.C. $\S 45 \mathrm{~b}(\mathrm{~g})$ (Supp. IV. 2016) ("Nothing in this section shall be construed to affect any cause of action brought by a person that exists or may exist under State law.”). 
or services." 244 The Maryland law has a nearly identical prohibition, except that it expressly states that the law is without prejudice to the rights of businesses to sue for defamation in a proper case. ${ }^{245}$ Illinois followed suit in 2017 and enacted a nearly identical provision (with no mention of defamation or other limitations). ${ }^{246}$ Other states have introduced bills, but to date none have become law. ${ }^{247}$

These state laws, unlike the CRFA, contain no exception allowing limited contractual bans of defamatory, abusive, or other reviews. Rather, according to the text of these laws, merchants subject to the law of California, Maryland, and Illinois (and any other state where such a limited law may be enacted) are completely prevented from putting any clause in their consumer contracts that limits abusive reviews posted by the trolls discussed in this article. Therefore, merchants subject to these laws should conduct themselves accordingly while this remains the case. This article contends that these states-and any other states that consider enacting their own state laws that prohibit consumer contract provisions banning nondisparagement clauses-would do well to consider modifying their statutes to allow for the sensible carve-out exceptions that Congress enacted in the CRFA, including the allowance for businesses to combat trolls with limited clauses banning abusive reviews. However, in the meantime, businesses subject to the laws in these states should not attempt to contractually ban reviews at all.

\footnotetext{
244 CAL. CIV. CoDE $§ 1670.8(a)(1)$ (West 2018). Moreover, unlike the CRFA, the California law allows consumers to bring direct actions against violating merchants, authorizing the recovery of a $\$ 2,500$ penalty for the first violation and $\$ 5,000$ for each subsequent violation; moreover, a $\$ 10,000$ penalty is authorized for a "willful, intentional, or reckless violation." Id. $\S 1670.8(\mathrm{c})-(\mathrm{d})$.

245 Md. Code ANn. CoM. LAW § 14-1325(e)(3) (West 2018).

246815 ILL. COMP. STAT. 505/2UUU (West 2018).

247 See The 'Right to Yelp' Is Now Maryland Law, NFIB (July 19, 2016), https://www.nfib.com/content/news/legal/the-right-to-yelp-is-now-maryland-law-74679/ ("[S] everal other states-Massachusetts, New Jersey, Oklahoma, and South Carolina-have considered similar legislation that hasn't passed."); NY Assembly Passes "Right To Yelp" Bill to Protect Consumer Opinions, THE CHRONICLE (May 17, 2018), http://www.chroniclenewspaper.com/apps/pbcs.dll/article?AID=\%2F20180517\%2FNEWS01 \%2F180519950\%2FNY-Assembly-passes-\%E2\%80\%9CRight-to-Yelp\%E2\%80\%9D-bill-toprotect-consumer-opinions (noting that a New York bill was introduced in May 2018 and is pending as of this writing).
} 


\section{CONSUMER REVIEWS, TROLLS, AND THE DUTY OF GOOD FAITH AND FAIR DEALING}

As seen in the previous section, the CRFA seems to allow continuing use of non-disparagement clauses forbidding online reviews which are either defamatory or abusive (subject, however, to the more limited laws in California, Maryland, and Illinois). However, many merchants may choose not to use such nondisparagement clauses, at least in the current environment where there is an apparent public opinion against anything that can be seen as restricting consumers' rights to express their opinions online (not to mention a fear of violating the newly-enacted and highly-publicized CRFA). And yet, the behavior of internet trolls in posting virulent, gratuitously hyperbolic reviews can be seen as unfavorable, given the combination of the malicious nature of the tone used coupled with the devastating and disproportionate effects such reviews can have on a business. Before concluding, therefore, this Article will explore one more potential avenue for dealing with abusive, troll-type consumer reviews. That avenue is the duty of good faith and fair dealing in contract.

\section{A. THE DUTY OF GOOD FAITH AND FAIR DEALING}

The duty of good faith and fair dealing is recognized by both the Restatement (Second) of Contracts and by the Uniform Commercial Code. Section 205 of the Restatement provides: "Every contract imposes upon each party a duty of good faith and fair dealing in its performance and its enforcement."248 Section 1-304 of the Uniform Commercial Code provides similarly. ${ }^{249}$ The meaning or definition of good faith and fair dealing is less accessible. The Uniform Commercial Code provides an express definition in the most recent formulation, which is that good faith "means honesty in fact and the observance of reasonable commercial standards of fair dealing." 250 The Restatement, however, resists a formal definition; the initial comments to the Restatement provision provide for an amorphous

\footnotetext{
248 RESTATEMENT (SECOND) OF CONTRACTS § 205 (AM. LAW Inst. 1981).

249 U.C.C. § 1-304 (AM. LAW INST. \& UNIF. LAW COMM’N 2017) (“Every contract or duty within [the Uniform Commercial Code] imposes an obligation of good faith in its performance and enforcement.").

$250 \quad$ Id. $\S 1-201(20)$.
} 
and flexible conceptualization of good faith. ${ }^{251}$ As the comments indicate, "[a] complete catalogue of types of bad faith is impossible." 252 Thus, the doctrine would appear to be flexible enough to accommodate bad acts by contracting parties of all kinds as they are encountered in practice.

There are some limits. The comments to section 205 indicate that the duty of good faith and fair dealing is not typically appropriate in the pre-formation stage of a contract; that is, there is generally no duty of good faith and fair dealing in the process of forming a contract. ${ }^{253}$ Rather, the duty of good faith and fair dealing generally applies only to the performance and enforcement stages of the contract relationship. ${ }^{254}$ With respect to enforcement, the comments to section 205 state that

The obligation of good faith and fair dealing extends to the assertion, settlement and litigation of contract claims and defenses. .. . The obligation is violated by dishonest conduct such as conjuring up a pretended dispute ... or falsification of facts. It also extends to dealing which is candid but unfair . . . 255

The duty of good faith and fair dealing has often been applied in scenarios where one party has some manner of discretion to act in a way that affects the rights of another party. For instance, when one party has the right to dictate whether he is "satisfied" with the other's performance (a so-called "satisfaction clause"), the party who has the power and discretion to announce his satisfaction must exercise such power in good faith. ${ }^{256}$ Good faith is also called for and

\footnotetext{
251 See Restatement (SECOND) of Contracts $§ 205 \mathrm{cmt}$. a (Am. LaW Inst. 1981) (“The phrase 'good faith' is used in a variety of contexts, and its meaning varies somewhat with the context. Good faith performance or enforcement of a contract emphasizes faithfulness to an agreed common purpose and consistency with the justified expectations of the other party . . ..”).

253 See id. cmt. c (noting that "bad faith" in negotiation may be punishable by other means).

254 See id. cmt. a, d, e (describing the phases of a contract to which the duty of good faith and fair dealing applies).

255 Id. cmt. e.

256 See, e.g., Locke v. Warner Bros., Inc., 66 Cal. Rptr. 2d 921, 925 (Cal. Ct. App. 1997) ("[W]here a contract confers on one party a discretionary power affecting the rights of the other, a duty is imposed to exercise that discretion in good faith and in accordance with fair dealing.").
} 
applied to requirements and output contracts under the Uniform Commercial Code, where the buyer entitled to demand supply of his requirements (or the seller entitled to demand purchase of his output) must do so honestly and in the exercise of good faith. ${ }^{257}$ One court has noted that the duty of good faith requires that "neither party ... do anything which will have the effect of destroying or injuring the right of the other party to receive the fruits of the contract." 258 The duty thus protects one party to a contract from the bad faith efforts of the other party to injure or damage them without just cause.

\section{B. APPLICATION OF THE DUTY OF GOOD FAITH AND FAIR DEALING TO ABUSIVE CONSUMER REVIEWS}

This Article proposes that the duty of good faith and fair dealing should be applied to the trolling or abusive review scenario as an implied obligation in all contracts, regardless of the presence of an express non-disparagement clause. In this scenario, the merchant and the consumer have clearly entered into a contract for the sale of goods or services, and thus, a duty of good faith and fair dealing is implied in all such contracts. Granted, at the time that most consumers post their scathing reviews of the merchant or its goods or services, the contract is seemingly "over" from the consumer's perspective. And yet, it is not really over. The merchant may have ongoing warranty obligations, or the consumer may have a period of time to request refunds or other contract rights. More importantly, a period of potential enforcement of rights still exists for a time after the bulk of the merchant's delivery of goods or services is completed. The consumer may have a right to pursue a cause of action for breach of contract, warranty relief, or other specific rights granted by the contract with the merchant or its terms of service. As indicated, the comments to Restatement section 205 establish that the duty of good faith and fair dealing extends to the enforcement stage, including the assertion of contract claims. ${ }^{259}$

\footnotetext{
257 See U.C.C. § 2-306(1) (AM. LAW INST. \& UNIF. LAW COMM’N 2017) (noting how the terms "output" and "requirement" mean the "actual output or requirements as may occur in good faith").

258 Locke, 66 Cal. Rptr. at 925 (emphasis added).

259 Restatement (SECOND) OF CONTRACTS $§ 205$ cmt. e (AM. LaW InSt. 1981).
} 
When consumers post negative reviews online of their experience with a merchant's goods or services, they are in fact asserting potential claims against the merchant-whether in breach of contract, breach of warranty, or otherwise. They are "litigating" their claims, perhaps not immediately in a court of law, but in the court of public opinion. Many times, these consumers are in fact seeking some sort of informal recompense from the merchant for their woes. ${ }^{260}$ Of course, such posts and online reviews could also conceivably lead to actual legal assertion of their rights. Thus, the duty of good faith and fair dealing should apply to the time period when consumer reviews are posted because this is still feasibly within the "enforcement" phase of the contractual relationship.

This Article thus proposes that the duty of good faith and fair dealing should apply to consumer reviews, and that it should follow the contours that have been established by the CRFA. That is, the duty should not be found to be violated when a consumer leaves a positive review. Neither should it be found to be violated when a consumer leaves a good faith, factually-based review about the actual problems with the goods or services purchased (e.g., "the steak was over-cooked, and was excessively dry"). As discussed in the previous section, such reviews are now protected by the CRFA, and I do not here propose any clever attempt to circumvent the limitations established by that statute. Stated another way, I would conclude that these reviews have been made and posted in good faith.

However, the excessive, gratuitously negative, virulently hyperbolic review (e.g., "the food tasted like PIG VOMIT! It was the WORST! I am surprised I did not DIE FROM THE DISGUSTING SLOP! DON'T GO HERE IF YOU VALUE YOUR LIFE!!!!!"”) is in bad faith and is thus a violation of the duty of good faith and fair dealing. The parties have a relationship established by contract. By leaving such an abusive review, the consumer is exercising the discretion he or she has to publicly comment on the goods or services purchased from the merchant and (at least indirectly) assert potential enforcement rights in contract and warranty in such a way

\footnotetext{
260 See Barnes, supra note 567, at 674-88 (discussing generally the acts of consumers posting on social media in order to extract benefits and concessions from merchants).
} 
as to injure the rights and livelihood of the merchant. ${ }^{261}$ The injury is very real even if the review does not rise to the level of defamation because of the "rhetorical hyperbole" or "fact or opinion" distinction. ${ }^{262}$ This Article argues that either the existing doctrine of the duty of good faith and fair dealing presently applies to such abusive reviews, or, alternatively, that it should be extended so as to apply to such reviews. As a leading contracts hornbook states, "[t]he concept of 'good faith' can be used in any situation to right a wrong that would be created if the traditional rule were applied." 263 Internet trolls posting abusive, virulent, and hyperbolic reviews, is such a situation where a right can be wronged-by making such reviews a violation of the contractual implied duty of good faith and fair dealing. ${ }^{264}$

\section{ADDRESSING POTENTIAL CONSTITUTIONAL CONCERNS}

Before concluding, I will address a potential problem with this proposal-the First Amendment. That is, since this Article's proposed operation of the contract duty of good faith and fair dealing will operate to prohibit "speech" of a certain type (abusive consumer reviews), the First Amendment's protections of free speech are at least potentially implicated. I conclude that the First Amendment is not an impediment to this Article's proposal because either: (1) there is no state action present to implicate the First Amendment, or (2) if there is state action, operation of this proposal will nevertheless not cause any First Amendment violation.

The first issue in a First Amendment analysis of this Article's proposal is whether state action is present at all. Although the U.S. Supreme Court has clearly held that tort actions can implicate the First Amendment, it has yet to make such a ruling with respect to

\footnotetext{
261 See Locke, 66 Cal. Rptr. 2d at 925 (noting that a party who has the discretionary power to impact another party's rights must exercise that power in good faith).

262 See SMOLLA, supra note 202, and accompanying text.

263 John D. Calamari and Joseph M. Perillo, The LaW of Contracts 461 (4th ed. 1998).

264 Of course, whether to seek to enforce the duty of good faith and fair dealing in the context of online reviews would be up to each individual merchant in question. Given the current negative publicity regarding perceived efforts to squelch online consumer reviews, many may not seek to enforce the duty, but rather may seek to remedy the situation by other means, particularly by reaching out to the aggrieved consumer in question.
} 
contract actions. ${ }^{265}$ There are arguments that enforcement of contract should not implicate state action. A contract is a matter of private ordering between the parties setting forth their obligations independent of the state. ${ }^{266}$ Therefore, the enforcement of contract is carried out by private parties, not any government. Thus, in many instances, there is clearly no state action involved when a court enforces a private agreement between two parties even when one party's speech is restricted by the agreement (such as in confidentiality clauses). ${ }^{267}$

However, some have pointed to other Supreme Court cases for the proposition that in certain instances state action can be implicated in a contract-like action. ${ }^{268}$ One such case used as an example is Shelley $v$. Kraemer, which involved restrictive property covenants purporting to require white-only owners for fifty years. ${ }^{269}$ In striking down the restrictive covenants as unconstitutional, the Court observed that state action was present given that the owners were using "the full coercive power of government" in order to deny "rights of property available to other members of the community."270 In other words, the Court observed that the issue was not as simple as one private party versus another private party-rather, outside parties were affected and purportedly denied the ability to purchase property. ${ }^{271}$ Since the property owners were trying to use the power of the state to enforce the covenants, not only against immediate parties with whom they were in contractual privity, but also to deny members of the public the right to purchase the property, the Supreme Court found that state action was involved. ${ }^{272}$

\footnotetext{
265 Garfield, supra note 129, at 347-48.

$266 \quad I d$. at 348.

267 See Belmas \& Larson, supra note 140, at 67 (citing State v. Noah, 9 P.3d 858, 871 (Wash. Ct. App. 2000) ("For the existence of a First Amendment violation, state action is required. State enforcement of a contract between two private parties is not state action, even where one party's free speech rights are restricted by that agreement.")).

268 See id. at 68 ("The Supreme Court has made it clear that enforcement of some private contracts does, indeed, constitute state action ....").

269334 U.S. 1,4 (1948).

$270 I d$. at 19 .

271 See Belmas \& Larson, supra note 140, at 68 ("The Court suggested that this case affects outside parties; it is not merely the state enforcing a contract voluntarily entered into by private parties.").

$272 I d$.
} 
Some commentators have pointed to cases like Shelley and analogized to "contracts of silence" like express non-disparagement clauses, or, as I propose in this Article, the operation of the duty of good faith and fair dealing so as to prohibit abusive consumer reviews. ${ }^{273}$ The argument is that the public may have an interest in hearing the speech that is being suppressed. ${ }^{274}$ The matter is not merely one between two private parties to contract, but rather, the public is affected too. ${ }^{275}$ Thus the argument goes that state action is present. However, there is a distinction. The CRFA's Paragraph (2)(C) provisions, and the duty of good faith and fair dealing, are only proposed by this Article to suppress abusive consumer reviews. The CRFA's policy rationale is to allow the continued free flow of legitimate, honest, good faith reviews. ${ }^{276}$ The CRFA allows libelous, abusive, and harassing reviews to be contracted against; this Article's proposal with respect to the duty of good faith and fair dealing similarly seeks to suppress abusive reviews. Public interest in honest, fair reviews - both positive and negative-is conceded, but the public interest in abusive reviews posted by trolls is surely much less. Given the lesser public interest in hearing from such trolls, any dispute between a merchant and an abusive reviewer is more akin to a purely private dispute than to a scenario like Shelley where legitimate public interests are implicated as well. As such, state action is arguably lacking with respect to the Article's proposal, and thus no constitutional difficulties are presented. ${ }^{277}$

However, even if state action is present, there is direct Supreme Court precedent that suggests there is no constitutional problem with using the implied duty of good faith and fair dealing to police abusive consumer reviews. ${ }^{278}$ Although there is no Supreme Court

\footnotetext{
273 See id. at 68-69 ("The Shelly line of argument can be extended into the gagwrap areas.").

274 See id. ("Even if an end-user voluntarily contracts with a software provider by accepting a EULA containing a gagwrap clause, the rights of the public to hear the restricted speech that user wants to express using that software are abridged.").

$275 I d$.

276 Consumer Review Fairness Act of 2016, supra note 171.

277 Another argument, at least with respect to expressly-stated obligations (such as an express non-disparagement clause), is that when a consumer agrees to such a contract she has waived any constitutional rights. Garfield, supra note 129, at 348. Although this argument has some force with respect to a contract where a consumer has signed an express non-disparagement clause, it is admittedly a much weaker argument when applied to a wholly-implied obligation, like the duty of good faith and fair dealing.

278 Cohen v. Cowles Media Co., 501 U.S. 663 (1991).
} 
case involving a purely private breach of contract action in this context, there is a Supreme Court case involving promissory estoppel-a contract-related doctrine. ${ }^{279}$ In Cohen v. Cowles Media Co., a person offered to give information about a political candidate to local news media on the condition of maintaining his anonymity. ${ }^{280}$ The reporters promised to keep the person's name confidential but in fact did not honor this promise and revealed his name in the published accounts. ${ }^{281}$ As a result, the person was fired by his employer, and then sued the publishers on tort and contract grounds. ${ }^{282}$ Although the person initially prevailed at trial, on appeals through the state court system both the tort and contract judgments were reversed. ${ }^{283}$ The Minnesota Supreme Court did, however, consider the propriety of a promissory estoppel claim, but ultimately decided that finding promissory estoppel liability against the newspapers for failing to honor the promise of confidentiality would violate the papers' First Amendment rights. ${ }^{284}$

The U.S. Supreme Court considered the First Amendment claims of the newspapers. ${ }^{285}$ The Court initially considered whether state action was present in the person's efforts to seek to hold the newspapers accountable under the doctrine of promissory estoppel. ${ }^{286}$ It noted that "[o]ur cases teach that the application of state rules of law in state courts in a manner alleged to restrict First Amendment freedoms constitutes 'state action' under the Fourteenth Amendment." 287 The Court went on to note:

[T] he Minnesota Supreme Court held that if [the person] could recover at all it would be on the theory of promissory estoppel, a state-law doctrine which, in the absence of a contract, creates obligations never explicitly assumed by the parties. These legal obligations would be enforced through the official power

\footnotetext{
$279 \quad I d$.

$280 \quad I d$. at 665.

281 Id. at 665-66.

$282 I d$. at 666.

283 Id. at 667.

284 Id.

285 Id.

286 Id. at 668.

287 Id.
} 
of the Minnesota courts. Under our cases, that is enough to constitute 'state action' for purposes of the Fourteenth Amendment. 288

Notwithstanding that the Court recognized the presence of state action in enforcing the promissory estoppel claim against the newspapers, it nevertheless found that there was no constitutional violation, based on the established precedents holding that "generally applicable laws do not offend the First Amendment." 289 The Court, in discussing a series of cases holding that generally applicable laws could be applied to the press without a First Amendment violation, noted that the press must comply with criminal laws against breaking and entering, copyright laws, labor laws, antitrust laws, and tax laws. ${ }^{290}$ After reviewing the established precedents with respect to laws of general applicability, the Court concluded:

There can be little doubt that the Minnesota doctrine of promissory estoppel is a law of general applicability. It does not target or single out the press. Rather, insofar as we are advised, the doctrine is generally applicable to the daily transactions of all the citizens of Minnesota. The First Amendment does not forbid its application to the press. ${ }^{291}$

The Court further observed that the doctrine of promissory estoppel was a state law designed to apply generally to all the

\footnotetext{
$288 I d$. I will note here that this statement by the Court could be used for both sides of the state action argument regarding the implied duty of good faith and fair dealing. On the one hand, note that the Court takes pains to mention it is applying state rules of law, in the absence of contract. In the proposal made by this Article, the parties will in fact be subject to an express contract with each other for goods or services. Thus, the argument remains that a purely private contract action involves no state action. However, I concede that the other side of this argument is that, like promissory estoppel, the duty of good faith and fair dealing is arguably a state-law created doctrine (albeit one designed to effectuate the presumed intent of the parties), and this is ammunition for the argument that state action is involved in a court enforcing the implied duty of good faith and fair dealing with respect to an abusive consumer review.

289 Id. at 669.

$290 \quad I d$. at 669-70 (citations omitted).

291 Id. at 670 (emphasis added).
} 
citizenry, in this case "a generally applicable law that requires those who make certain kinds of promises to keep them." ${ }^{292}$

The contract-related implied duty of good faith and fair dealing is a state law doctrine that, like promissory estoppel, is a law of general applicability. Whereas promissory estoppel is a rule that generally requires all citizens to keep their promises where there has been detrimental reliance, the duty of good faith and fair dealing is a rule of general applicability that requires all parties that have entered into contracts to treat the other party in a good faith manner, and not to utilize their discretion so as to injure or damage the other party. ${ }^{293}$ The court called upon to enforce the duty of good faith and fair dealing against an abusive consumer reviewer is not selecting or targeting the speech to be suppressed-rather, it is applying a general principle that can be applied to many different kinds of conduct. ${ }^{294}$ Given that the press in Cohen was not given a pardon on their obligation as citizens to comply with laws of general applicability, it follows that individual consumers posting abusive reviews should likewise be compelled to conform to rules of general applicability, including treating their contracting partners with good faith and fair dealing. Therefore, under the constitutional principles described and applied in Cohen, applying this Article's proposal to use the implied duty of good faith and fair dealing to prohibit abusive consumer reviews should pass constitutional muster.

\section{CONCLUSION}

The internet has fundamentally transformed many aspects of our lives. One of these transformed aspects is the widespread availability of information about merchants and the goods and services that they sell to the public. ${ }^{295}$ Consumers have more

\footnotetext{
292 Id. at 672 . The decision was decided on a 5-4 basis, and there were two dissenting opinions. However, the dissents were primarily focused on the particular role of the press in the case. Justice Souter conceded in his dissent: "This is not to say that the breach of such a promise of confidentiality could never give rise to liability. One can conceive of situations in which the injured party is a private individual, whose identity is of less public concern than that of petitioner; liability there might not be constitutionally prohibited." Id. at 678-79 (emphasis added).

293 See supra notes 256-258 and accompanying text.

294 See supra notes 248-252 and accompanying text.

295 See supra notes $27-38$ and accompanying text.
} 
information than ever before, imperfect though it may be, based on the ability and willingness of other consumers to post reviews about their experiences with merchants, goods, and services. These reviews are posted on websites, social media, and many other online spaces. Such reviews are a rich source of information about others' transactional experiences, and an increasing number of shoppers say that they rely on such information in informing their purchases. ${ }^{296}$

From the standpoint of the consumer, these reviews are a boon to the purchasing experience as they facilitate the free flow of information about prospective purchases and help consumers make more informed purchase decisions. ${ }^{297}$ From the standpoint of the merchants, of course, the reviews can be critical to the success or failure of their businesses. Positive reviews boost sales, ${ }^{298}$ but negative reviews can have the opposite effect. ${ }^{299}$ And although most reviewers post factual, descriptive narratives about their experiences, the nature of the internet and "troll-like" behavior sometimes leads to hyperbolic, over-the-top, severely, and gratuitously negative reviews. ${ }^{300}$ Rationally fearing a disproportionate negative effect of such reviews on their businesses, some merchants have tried to fight back in the form of implementing non-disparagement clauses in their contracts. ${ }^{301} \mathrm{~A}$ handful of publicized instances about merchants enforcing (or threatening to enforce) such clauses led to backlash and ultimately resulted in Congress enacting the Consumer Review Fairness Act (CRFA), which significantly restricts the legality of such clauses. ${ }^{302}$

However, in most of the country (everywhere except California, Maryland, and Illinois, which have more restrictive laws as discussed in Part III.D) we can have it both ways. The CRFA preserves the right of consumers to post reviews of their purchases and experiences and thus continues to give the benefit of such informational exchanges to prospective consumers to make the best purchase of goods, go to the best restaurant, book the best hotel,

\footnotetext{
296 See supra Part II.B.

297 See supra notes 37-56 and accompanying text.

298 See supra notes 75 and accompanying text.

299 See supra notes 80-85 and accompanying text.

300 See supra Part II.c.3.

301 See supra Part II.D.

302 See supra Part III.A.
} 
etc. ${ }^{303}$ However, this Article argues that merchants still have two recourses against abusive reviews (which are not part of the legitimate information exchange sought by the ideal of the availability of such reviews). First, the CRFA itself does not prohibit form contract clauses that prevent the consumer from posting reviews that are defamatory or "abusive." These virulent, troll-like posts ("the food tasted like PIG VOMIT!") are abusive and are within the ambit of the CRFA's carve-out. ${ }^{304}$ Second, contract law implies a duty of good faith and fair dealing in all contracts, applicable to the performance and enforcement of such contracts. This duty requires that contracting parties do not use their discretion in such a way as to destroy or injure the other party to the contract. ${ }^{305}$ But, these troll-like, abusive reviews seek to do exactly that. Such reviews violate the implied duty of good faith and fair dealing even in the absence of an express non-disparagement clause in the contract (or even in the absence of a written contract at all). ${ }^{306}$ This Article also argues that the operation of this generally applicable legal principle presents no significant constitutional issues. ${ }^{307}$

Merchants should not be kept hostage as abusive internet trolls seek to destroy their businesses with unnecessarily hostile, virulent, over-the-top reviews. Such activity may be increasingly common in the age of the internet, with its various dark corners where undesirable activity runs rampant, but that does not make it any more acceptable. Everyone is enriched when such conduct is denounced, and tools are given to reduce its occurrence.

\footnotetext{
303 See id.

304 See supra Part III.B.

305 See supra Part IV.A.

306 See supra Part IV.B.

307 See supra Part IV.C.
} 